4H FOL10

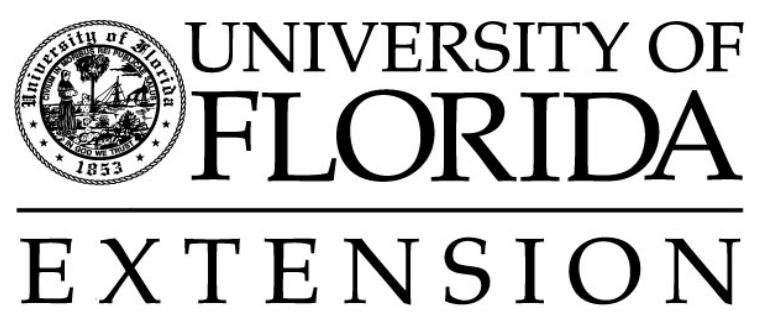

Institute of $\mathbf{F}_{\text {ood and }} \mathbf{A}$ gricultural $\mathbf{S}_{\text {ciences }}$

\section{Forest Resources} Leader Guide

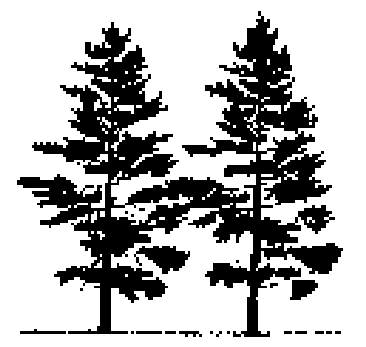

\section{Florida 4-H Project Book}

Florida 4-H Project Book Forest Resources Leader Guide
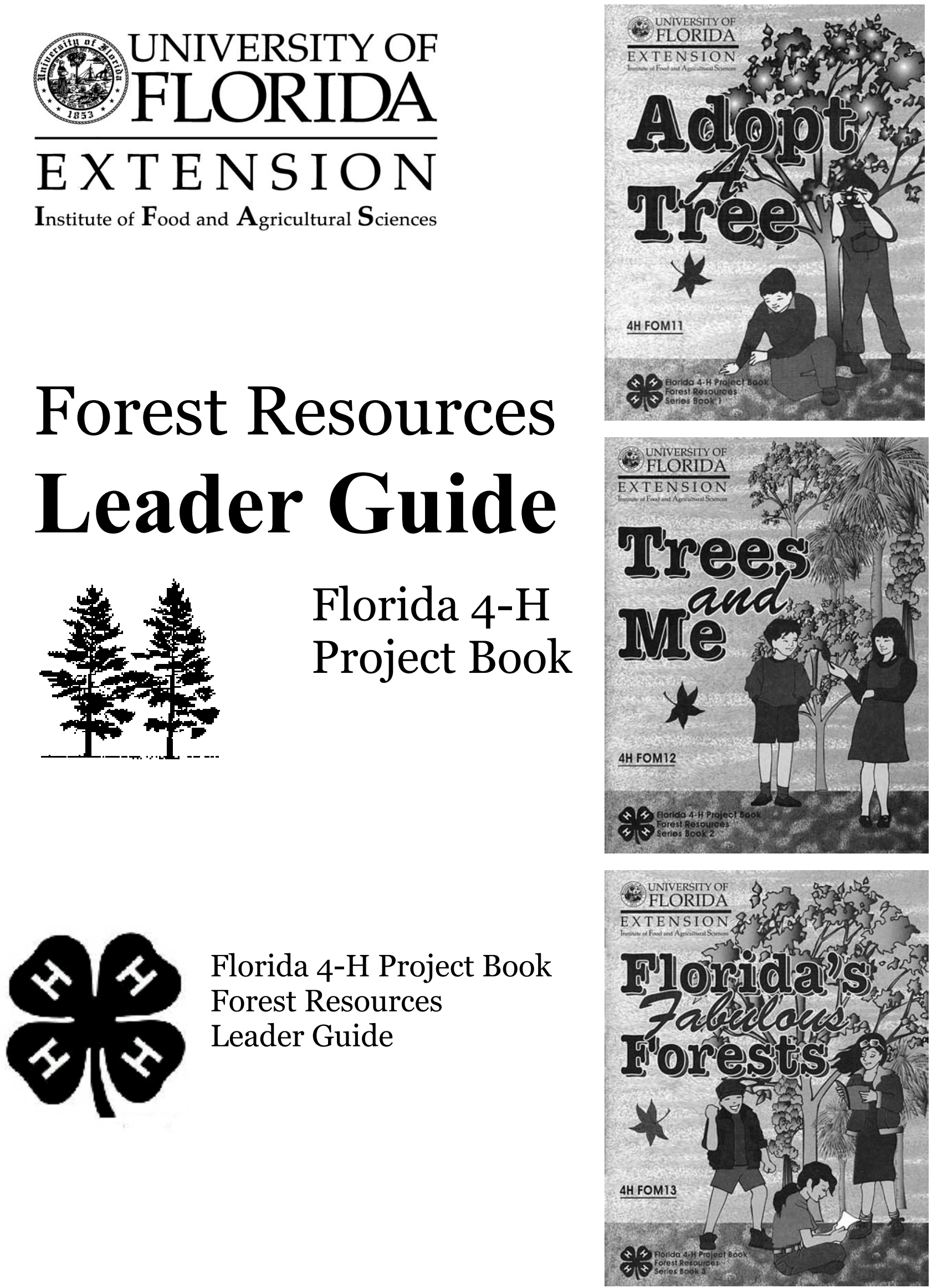


\title{
Forest Resources Leader Guide: \\ Florida 4-H Project Book
}

For the Forest Resources Project Book Series:

\author{
Adopt a Tree - 4H FOM11 \\ Trees and Me - 4H FOM12 \\ Florida's Fabulous Forests - 4H FOM13
}

Martha C. Monroe

School of Forest Resources and Conservation

University of Florida

2001 


\section{Acknowledgments}

I would like to acknowledge and thank those who helped write and edit these materials to guide teachers and club leaders as they embark on an exploration of Florida's forests with youth:
Alison Bowers
Jeanette Randall
Wayne Smith
George Blakeslee
Alan Long
Tim Martin
Jerry Culen
Stan Rosenthal
Marcus Boston Jr.

Special thanks go to Sonya Leonore Stahl who provided the graphic design and format for these materials and helped assemble the Forest Resource Boxes for county agents to use with club leaders.

The Forest Resource Boxes were made possible by funding from the School of Forest Resources and Conservation, University of Florida and the Florida Division of Forestry's Urban and Community Forestry Program. 


\section{Welcome!}

Welcome to the Leader's Guide for the project books in the Forest Resources Series. These books were written to encourage youth-as individuals, in clubs, and in classrooms-to learn about and explore the world of forests in Florida. This manual will provide the Project Helper, Club Leader, or Teacher with interesting background information, tips for successful experiments, and ideas for extensions if youth are motivated to go beyond these books.

This manual covers the following three project books in the Forest Resources series:

Adopt A Tree - By getting to know one nearby tree, youth will become introduced to the world of woody plants, including three special trees to Florida: Cabbage Palm, Live Oak, and Longleaf Pine. This booklet does not require much writing, as it is designed for 6-8 year old youth, though the discussion questions can be adapted to written assignments.

Trees and Me - Youth ages 8-11 will explore their many connections to trees in this project book, looking at trees in the city, trees in the park, trees around the grocery store, and trees around their home. From tree biology to the many benefits of trees and wood products, a host of project ideas will keep young people busy. Teachers can adapt the written questions and Challenges to complete a unit and build skills.

Florida's Fabulous Forests - Building on their knowledge of trees, youth ages 12-16 can use this book to investigate the forests of Florida. Some components of the forest ecosystem-soil, water, plants, and animals-make up several of the important aspects of this book. Youth will explore the influences of such factors as fire and invasive exotic plants on ecosystem structure. Written questions and a variety of project ideas prompt youth to reflect on important aspects of science and communication. This project may be completed in several months or two years, or used as a starting point for a long-term community project.

These project books are supported with three other elements of the 4-H program, in addition to this Leader Guide. We have developed a 4-H Forest Ecology Website to help youth learn to identify the forest plants in Florida. This website was developed with resources from the University of Florida 4-H Foundation to assist youth in their preparation for the Forest Ecology Contest. Your participants are encouraged to join the fun each year. Information about the contest can be found on the 4-H Forest Ecology Website, http://www.sfrc.ufl.edu/4h 
The annual 4-H Forest Ecology Contest is held at the Austin Cary Memorial Forest in Gainesville.. The winning state team has an opportunity to compete at the National Forestry Invitational, held every August in West Virginia. The 4-H member who is the highest scorer in the Contest receives a scholarship if he/she enrolls in the school of Forest Resources and Conservation at the University of Florida.

And finally, County Extension Offices have a Forest Resource Box filled with tools to help club leaders, teachers, and project helpers assist youth with the activities in these project books. The activities that require special tools are noted in this Leader Guide. Ask your 4-H agent if you can borrow the box!

Each activity in these books was designed to teach a concept through exploration or investigation, providing new information with readings or observation. The concept is strengthened through reflective questions that help the youth focus on their observations and experiences. Additional questions prompt learners to imagine new applications of each concept. Project ideas are included with the activities as inspiration for further investigation and application.

To complete each project book, participants must finish the required number of activities and projects to your satisfaction. Please check "Charting Your Progress" in each book for the recommended requirements. Of course, good ideas and motivated youth groups are encouraged to create projects that meet their needs. Work with your 4-H agent to make appropriate adaptations.

To enhance the concepts in these booklets, educators can look to Project Learning Tree, a national environmental education curriculum supplement. The PLT activities that relate to each activity in these project books are described under the heading "PLT Connection." You can get your own PLT materials in 2001 by calling the Florida Forestry Association at 850-222-5646, or after 2002 by contacting the University of Florida 4-H office at 352-846-0996. The PLT Guide is an excellent source of classroom activities with background information, student handouts, and discussion ideas to help groups of students learn about forests. Because PLT is a national resource, these $4-\mathrm{H}$ project books provide a helpful and appropriate Florida complement. 


\section{Table of Contents}

Adopt a Tree - Leader's Notes........................................................... 1

1. Selecting Your Tree ......................................................................................... 2

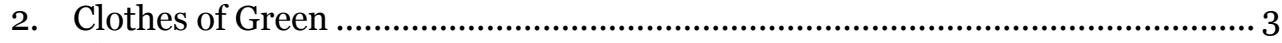

3. The Great Tree Cover-up ................................................................................... 5

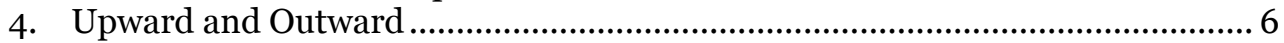

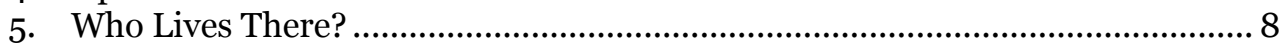

6. Our State Tree................................................................................................... 9

7. A Gracious Southern Tree ………………..................................................... 10

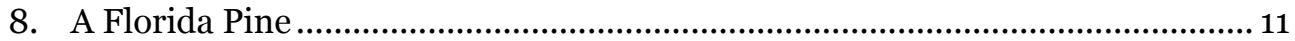

Trees and Me - Leader's Notes.....................................................12 Chapter 1: Tree Basics

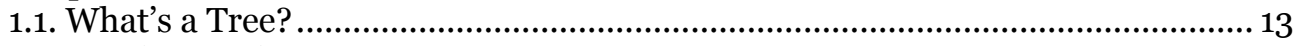

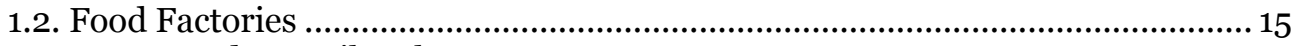

1.3. How Wood You Like That?................................................................................... 17

Chapter 2: Getting to Know Florida Trees

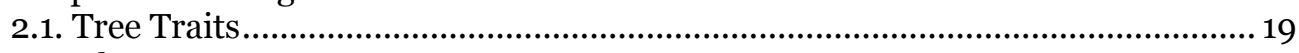

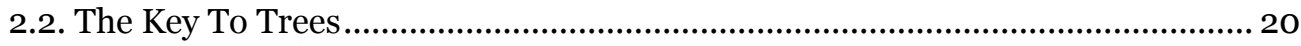

2.3. A Tree's Favorite Place ..................................................................................... 22

2.4. City Trees.......................................................................................................... 24

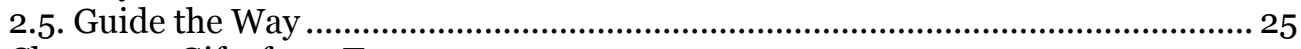

Chapter 3: Gifts from Trees

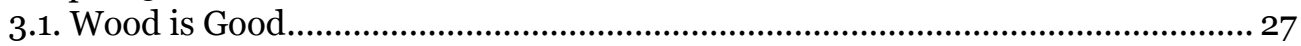

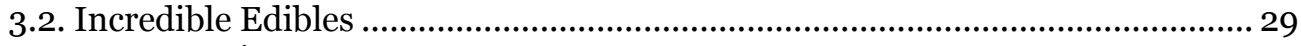

3.3. Tree Surprises ................................................................................................ 31

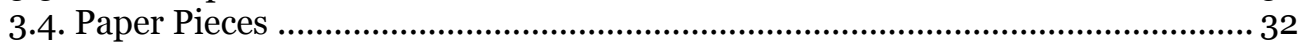

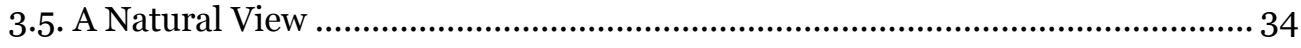

Florida's Fabulous Forests - Leader's Notes .....................................36

Chapter 1: Introducing the Forests

1.1. A Walk in the Woods............................................................................................... 37

1.2. So What's a Forest? ............................................................................................ 39

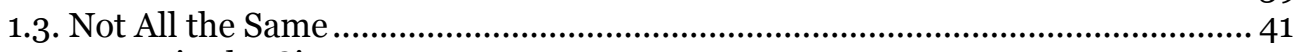

1.4. Forest in the City …...................................................................................... 42

1.5. A Working Forest.......................................................................................... 44

Chapter 2: Elements of Forests

2.1. Who Calls this Home? ........................................................................................ 45

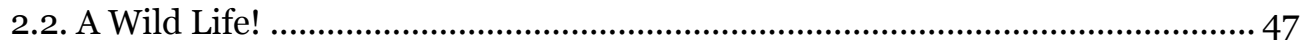

2.3. In Danger...................................................................................................... 48

2.4. Get Your Hands Dirty ...................................................................................... 50

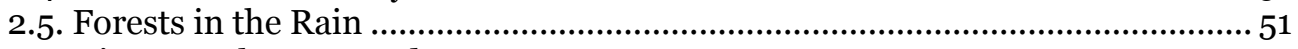

2.6. It's Natural to Succeed ..................................................................................... 52

Chapter 3: Managing Forests

3.1. It's Not So Clear Cut ..................................................................................... 54

3.2. Tree Doctor...................................................................................................... 56

3.3. Friendly Flames................................................................................................ 57

3.4. Be Prepared!................................................................................................... 59

3.5. Visitors from Far and Away .........................................................................60

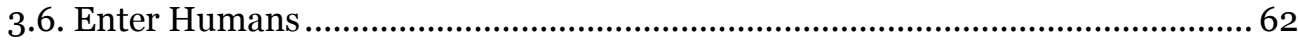




\section{Adopt A Tree Leader's Notes}

This book can be used with young children with limited reading and writing skills by reading the directions and discussion questions aloud.

Encourage youth to make careful observations and draw their findings in the book. You can easily adapt the project book for early readers by letting them read the directions and helping them write their responses to the questions.

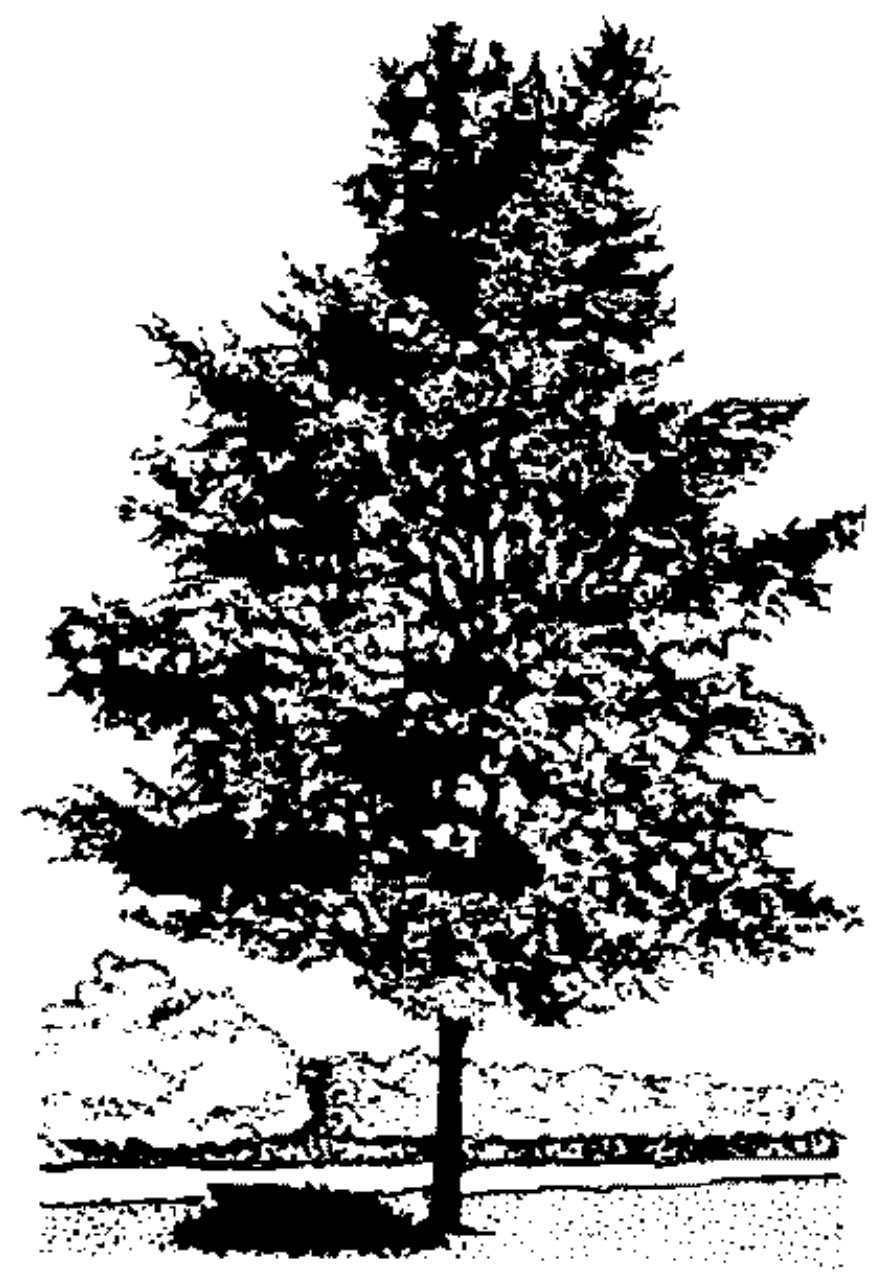

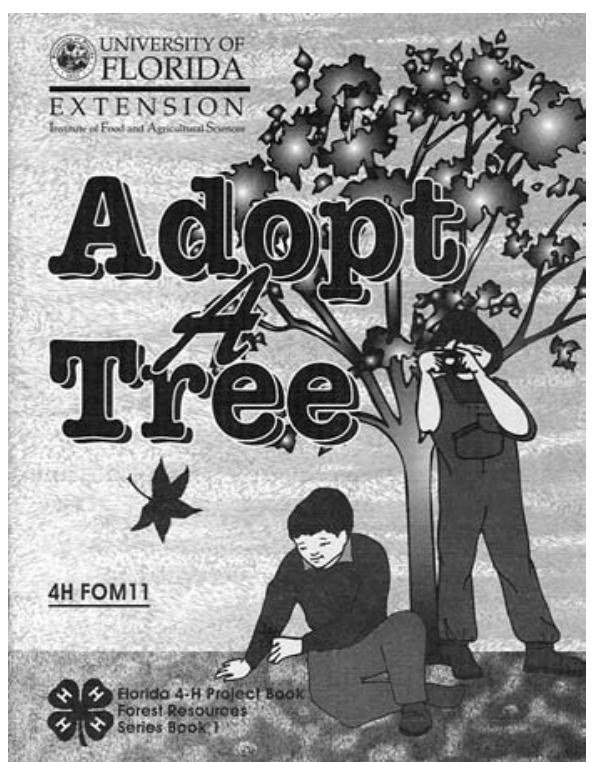




\section{Activity 1: Selecting Your Tree}

\section{Skill: Observation \\ Project: Find and get to know a special tree}

Help your 4-H'er choose a tree to adopt. Of course he/she won't take their tree home or nurture it as they might an adopted sibling or pet, but they can establish a relationship with their "own" tree. It should be a tree that can be easily and frequently visited-on the way to school, in the yard, or in a nearby park, for example. Pictures, poems, and photographs may be used to record observations and inspirations about the newly adopted friend. This tree will be used in the next four activities.

\section{Discussion Question Clues:}

A tree is a woody plant with a single, tall stem, or trunk. Most trees have woody tissue that enables them to continue to grow each year, rather than dying back over the winter. Many plants have woody parts but differ from trees due to their short stature or presence of many stems, like shrubs.

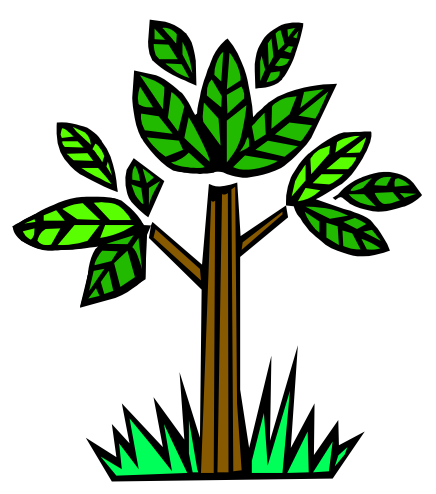

Challenge \#1: Trees change over time in subtle ways. As shoots grow, new leaves appear as they develop from new growth and older leaves disappear as they are shed from the older growth. Flowers and fruits appear, and stems grow longer. A bird may build a nest in a tree and then abandon it when he/she migrates. Encourage youngsters to start noticing such differences.

\section{PLT connection:}

Activity \# 21 suggests a variety of ways to help youth explore their tree in

\section{Adopt a Tree.}

Activity \#61, The Closer You Look, involves observing trees and drawing pictures.

Materials Needed: Crayons, markers, pens, or pencils 


\section{Activity 2: \\ Clothes of Green}

\section{Skill: Comparing and contrasting Project: Make a leaf print}

Trees have many different types of leaves, or "green clothes," which are the photosynthesizing structures of the tree. A bud, protected by some scales, may be found at leaf bases, branch tips, and along stems. It is the growing part of a tree that will develop into new tree parts like leaves and flowers. In a palm tree, there is only one bud and is at the top of the trunk. The leaf of a palm is an entire frond. In a pine tree, the leaf is a bundle of needles that vary from two to five per bundle. In broad-leafed trees, leaves come in many sizes and shapes and can be fun to draw or use for rubbings. By collecting leaves from several trees, it will be easier to see variation and differences between them.

Of course it is easier to do this activity when there are leaves on the tree. Spring is a good time to watch buds open into leaves (if $4 \mathrm{H}$ 'ers watch carefully every day), but during most of the summer and fall there should be a variety of different leaves for youngsters to find.

Photosynthesis is the process that allows green plants to convert sunlight, water, and carbon dioxide into simple sugars that serve as the source of energy for plant growth and the source of molecules for producing new growth.

Photosynthesis also produces oxygen as a byproduct. Almost all animals eat food and consume oxygen that is based on green plants. Oxygen that people breathe is recycled through green plants, too!

The terms hardwood, softwood, evergreen, and broad-leaf (or deciduous) are often used when talking about trees. People may or may not mean what they say! The terms softwood and evergreen usually refer to pine, spruce, fir, cypress, cedar,
Challenge \# 2: It would be easiest to choose leaves from five different trees, but an observant child may find differences in five leaves from the same tree!

PLT Connection: Activity \#64, Looking at Leaves, provides additional instructions for guiding youth through an exploration of leaves. Six different art activities with leaves are also included.

Materials Needed: Crayons, paper, and tape measure or ruler

Forest Resource Box: You can find both a tape measure and ruler in the box. 
and other cone-bearing trees. They are called "evergreen" because they keep their needles all year. Cypress trees, however, drop their needles as winter approaches each year, and some "softwoods" have very hard and durable wood!

The terms hardwood, broad-leaf, and deciduous usually refer to all the other forest trees, like maple, oak, hickory, magnolia, dogwood, etc. These trees do not have needles, and lose their leaves when the days grow short in preparation for winter. Some of our broad-leaf trees, like live oak and magnolia, do not lose their leaves in the fall. Their leaves fall off during the year as the new leaves open up.

Palms and cycads are not usually discussed in the same conversation as other trees in North America because they are neither softwoods nor hardwoods and due to climate, they are not widely found. But they are fine, woody plants that have many uses and because they grow in Florida, they are included as trees in these project books. They are very different from hardwoods and softwoods, however, in their seeds, stems, buds, and flowers.

\section{Discussion Question Clues:}

Leaves and needles may show slight variation on a tree. Leaves in the shade at the bottom of the tree may be bigger than those in the sun at the top. Some leaves may show signs that insects were feeding on them. Needles at the tip of a branch (this year's new needles) will be younger and smaller than needles farther down the branch. Those may be two or three years old.

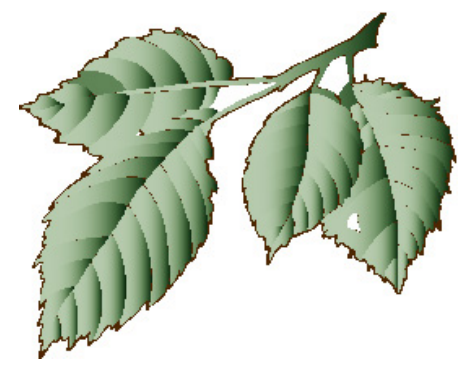




\section{Activity 3: The Great Tree Cover-up}

\section{Skill: Communication Project: Make a bark rubbing}

Bark is the outside layer of a tree, found on the trunk, branches, twigs, and roots. As a tree gets bigger, the bark splits, since it is no longer living tissue and cannot grow. Different trees have different patterns in their bark. Some trees have flaky, chunky bark like black cherry. Some have smooth bark with shallow cracks like American beech. Some have deep crevices while others appear as a maze of interwoven ridges, like pignut hickory. Color varies, from white to black. Bark changes as a tree ages. On a sycamore, smooth, greenish-gray bark begins to flake off on older trees, revealing lighter, younger bark underneath. This gives the bark of older sycamore trees a multicolored, mottled look. Some other Florida trees with distinctive bark are hophornbeam and sugarberry.

\section{Discussion Question Clues:}

Bill Brennan, a performer of children's songs about the natural world, wrote a song about bark many years ago, but the words are still true today. You can find this song on Billy B's recordings.

This bark on me is my skin. It keeps diseases out and tree juices in.

It protects me from bugs, dust, and wind.

Even though sometimes the bugs get in.

So the woodpeckers come and they make their marks, saying,

"Knock, knock, knock! We're hungry and there's bugs in your bark."

But, if the bark breaks, disease may set in, killing me,

Just because of broken skin.
Challenge \#3: A neat and orderly presentation of rubbings and descriptions would make a very fine booklet.

\section{PLT Connection:} Activity \#63, Tree Factory, describes a group drama where youth act out the part of a tree. Activity \#2, Get in Touch with Trees, encourages exploring the different textures of trees though the sense of touch.

Materials Needed: crayons, paper 


\section{Activity 4: Upward and Outward}

\section{Skill: Observation and measurement Project: Learn vocabulary and measure a tree}

The specifics of tree growth are not as important as the basic concept-they grow up and out from the edges. Even below ground, the tree roots grow down a little and out! In hardwood and softwood trees, the tip of each branch has buds that will make that branch elongate-making the tree taller and bigger all over. Special cells in the trunk increase the diameter of the tree. The old cells die and the bark on the outside of the tree may flake off. The living cells do the work of transporting water and nutrients throughout the tree.

What you see when visiting the same tree over a period of time will depend on what season or months of the year you choose to visit. If you arrive in January and watch through March, you should see the new leaves pop out of buds. If you visit between April and October, the leaves may get eaten by insects or attacked by pathogens, but otherwise may not change.

Leaves of broad-leafed trees (not needles) are positioned on a tree opposite each other or alternately down the branch. This is a key characteristic for identifying trees. Help your 4H'er check several branches on your adopted tree before deciding which you have.

Your 4-H'ers may need help measuring their tree. To find the circumference of the tree, help them hold the tape measure as they wrap it around the tree at about 4.5 feet above the ground. Next, provide assistance as they divide their measurement for the tree's circumference by 3.14 (an approximation of $\pi$, called pi and pronounced 'pie'). For example, if they found the tree's circumference to be 44 inches, divide 44 by 3.14 to get 14.01. The tree's diameter at breast height $(\mathrm{DBH})$ is 14.01 inches.
PLT Connection: Activity \#65 is all about buds. Bursting Buds encourages youth to explore the buds on twigs after leaves have dropped in the fall (many trees have visible buds when the leaves are still on the tree). Activity \#67, How Big Is Your Tree? involves measuring trees and the variation of this activity is particularly appropriate for younger children.

Materials Needed: crayons, calculator, tape measure

Forest Resource

Box: A tape measure is included in the box. 


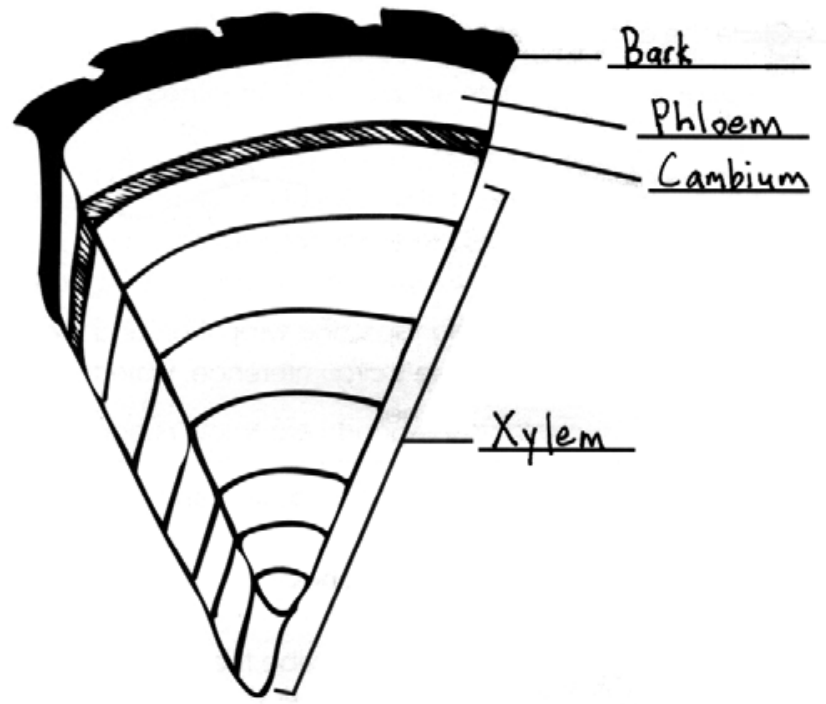

Youth should complete the drawing on page 16 in this way.

\section{Discussion Question Clues:}

If hands grew like trees, each finger would get longer and longer every year. If trees grew like people, a sign might be dangling from the trunk, 20 feet in the air! This is a basic difference that keeps plants and animals in two separate kingdoms.
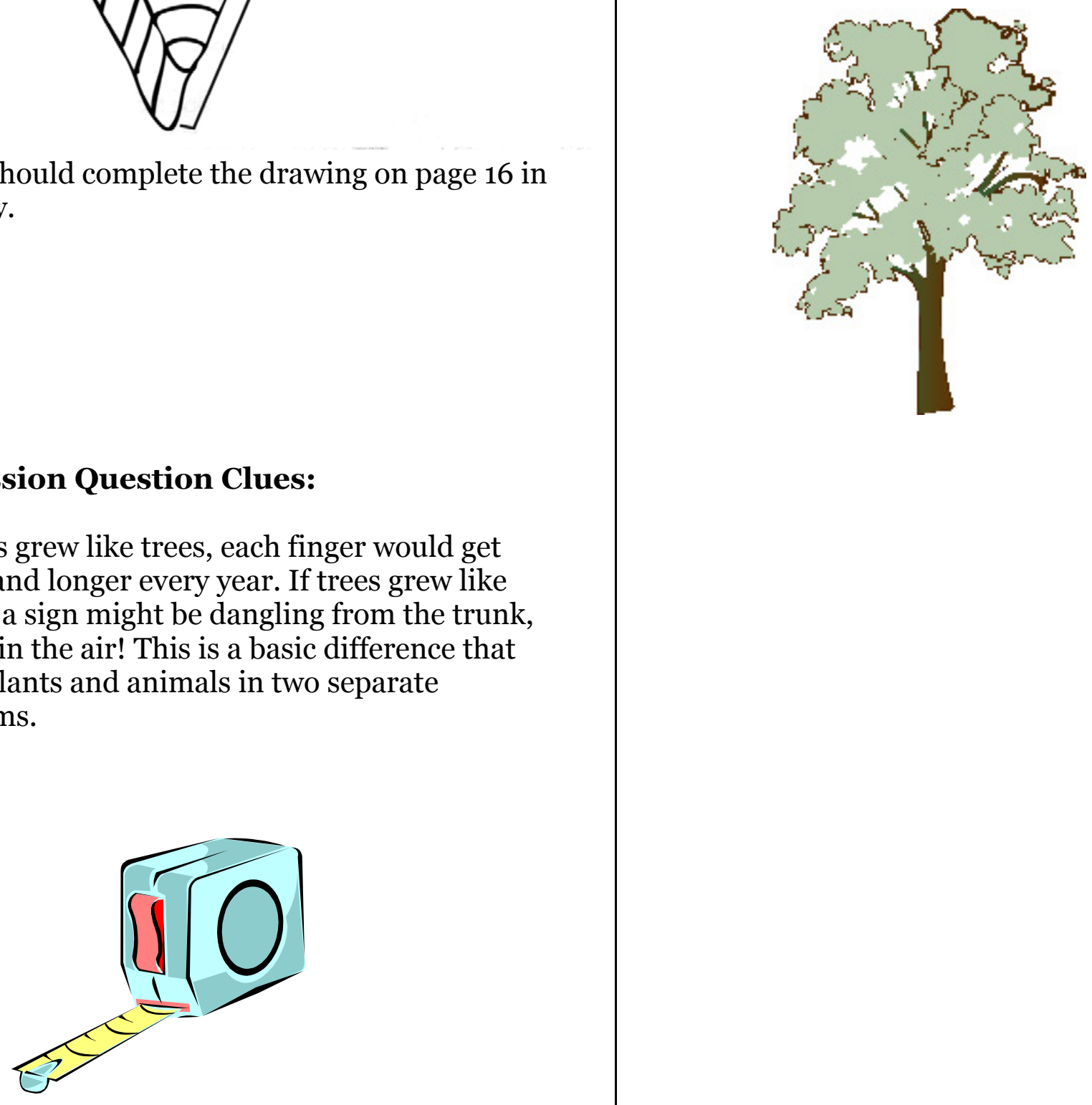


\section{Activity 5: Who Lives There?}

\section{Skill: Communication and observation Project: Observe animal life near the tree}

Many trees in Florida provide a place for other plants to grow: Spanish moss, ball moss, and resurrection fern are the most common. Many insects, spiders, squirrels, birds, and other animals probably visit the adopted tree, too. It takes a careful observer to find the evidence that these animals have been to visit. If the evidence isn't readily apparent, try exploring a tree at the water's edge, or at the edge of an undisturbed forest. Trees in parking lots or playgrounds may show more signs of human visitors than wild ones!

\section{Discussion Question Clues:}

More wild animals are on the move in the early morning and twilight hours, when it is harder for their predators to find them. Many animals use camouflage techniques, making it hard to be seen. The diamond, multicolored pattern of the eastern diamondback rattlesnake blends in with many of the snake's habitats. The tree frog's green appearance helps it blend into the foliage of trees. All types of animals might visit your 4-H'er's tree for food, shelter, hiding places, or perching places from which to view the world. Areas along the edges of rivers and the outer edges of forests where two ecosystems come together often get more animal visitors because they offer protection. Edges allow animals to escape into the forest while increasing the visibility of food sources in the adjoining open places. The center of a forest will have those animals that need lots of forest, but not those animals that need open space. The forest edges may have animals that need lots of forests, animals that need open space, and animals that need both forests and open space.
Challenge \#4:

Encourage creativity in the story. Help your 4H'er think about the animals that could visit the tree, even if none were seen.

Challenge \#5: A web of life, with the adopted tree in the middle, could have things like: sun, water, air, and space on one side, and things like Spanish moss, herons, mockingbirds, leaf rollers, and leaf miners on the other!

\section{PLT Connection:}

Activity \#22, Trees as

Habitats, encourages

youth to examine a tree or group of trees as potential habitats for other plants and animals. Activity \#8, The Forest of S.T. Shrew, provides a story to read about the animals and plants that live in the forest. Children can draw pictures to accompany the story. Activity \#46, School Yard Safari, invites everyone to go on a safari in a nearby area to look for signs of animal life. 


\section{Activity 6: \\ Our State Tree}

\section{Skill: Learning to learn \\ Project: Color a picture of our state tree}

The cabbage palm, Florida's state tree, is also called the sabal palm or the sabal palmetto. It is native to Florida and can be found across the state in a variety of forest ecosystems including hardwood hammocks, swamps, and tropical hammocks where there is limestone in the soil profile. They are commonly transplanted along new roadsides without any fronds (leaves). If there is enough water stored in the trunk, the tree can put out a new set of fronds and grow new roots. Notice that the top of the trunk is made of the interwoven bases of old fronds.

Be sure to notice the roots in the picture of the cabbage palm on page 20. Compare these roots to the roots of the longleaf pine on page 24 .

\section{Discussion Question Clues:}

Since there is only one bud on each tree, if the bud is damaged in a storm (or eaten) the tree will die.

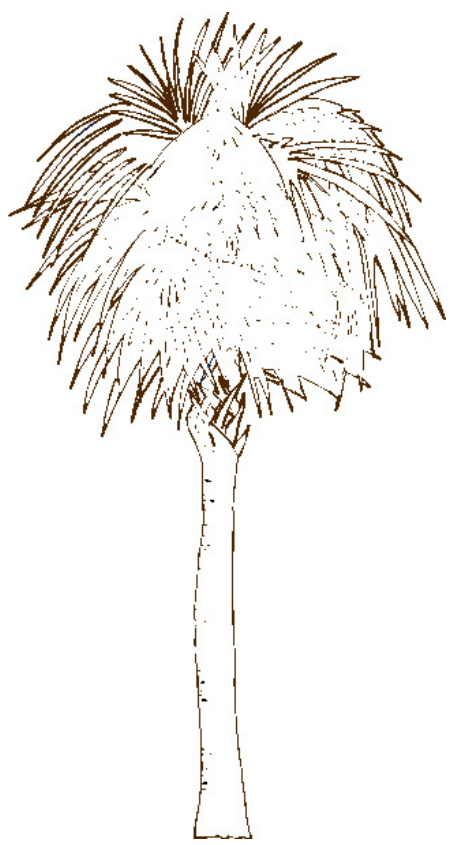

Challenge \#6: A city tree specialist will have some ideas of how people can protect and encourage trees in Florida. Try contacting the city park

department, the county forester, the extension service, or a landscaping firm for ideas. The Florida Urban Foresters Council can provide information on urban forestry in your area. Visit their website at http://www.fufc.org or call (407) 872-2738.

Challenge \#7: At least one other state has a cabbage palm as its state tree. The story of how certain trees are chosen as state trees may be interesting.

Materials Needed: Crayons 


\section{Activity 7: \\ A Gracious Southern Tree}

Skill: Learning to learn

Project: Color a picture of a Florida oak tree

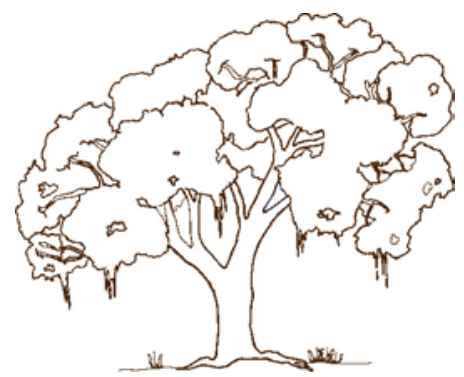

Live oak trees grow all over Florida, and can live to be a couple of hundred years old. Live oaks were the first commercially important forest tree in Florida, prized for ship construction. Today, live oak is a prominent urban tree, due to its ability to grow in many conditions, survive storms, and make lots of shade. Some communities have ordinances about planting trees in the city, how to trim trees under electric wires, and how to care for them.

Like the live oak, some of the other oaks found in Florida keep their leaves throughout the winter months. Oak trees that are green during the winter include live oaks, laurel oaks, or one of several other oaks. These trees are known as "semievergreen" because the old leaves fall off when the new leaves develop, allowing the tree to always have leaves. Other native oaks like Shumard, blue jack, and turkey oak lose their leaves in the fall like many northern oaks. Use other characteristics such as leaf shape to identify what type of oak a tree is.

\section{Discussion Question Clues:}

The acorns of the live oak are 3/4" to 1 " long, with a light brown cap that covers a small part of the shiny, dark brown nut. The acorns occur singly or in clusters of three to five nuts, and they mature in one season, dropping off in the fall. They provide a good food source for many animals such as squirrels and deer.

Challenge \# 8: The trees listed are interesting Florida trees and there are many more exciting trees in Florida. Information on Florida trees can be found at the 4-H Florida Forest Ecology website: www.sfrc.ufl.edu/4h. For an additional challenge, encourage your 4-H'er to select several trees that are common in your area and for which there is information available.

\section{Materials Needed:} Crayons

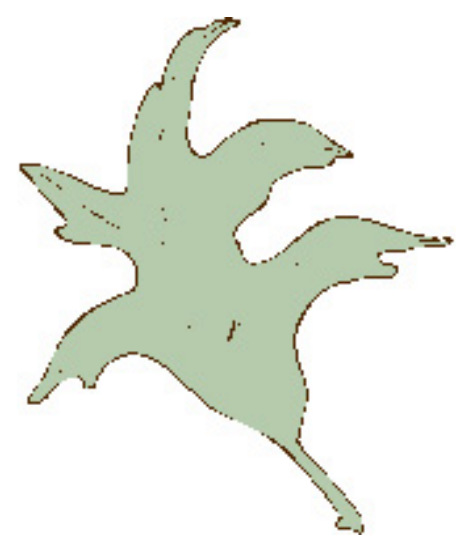




\section{Activity 8: A Florida Pine}

\section{Skill: Comparing and contrasting Project: Learn about pine trees}

Longleaf pine trees used to grow abundantly in many places in Florida, and as a result, can be found in many ecosystems here today. But they are not as common as they once were. The great longleaf forests were used to build homes, barns, cities, and railroads up to the early 1900 . This distinctive tree holds its needles near the tip of its stout, thick branches. The fine wood from large trees can be used for many wood products but is prized for flooring, beams, and a myriad of other uses. In recent years, people have recovered pine logs that were sunk in the rivers of Florida approximately one hundred years ago when rivers were the primary means of transporting logs from forest to city. The "river-raised" wood is very valuable.

\section{Discussion Question Clues:}

Longleaf pine is well adapted to frequent, low intensity fires. The seedling has a main bud that is protected by a heavy sheath of needles, making the seedling appear as a tuft of grass. These protected buds allow the longleaf pine to tolerate low intensity fire in the seedling stage. When the tree gets big, its thick bark makes it more fire tolerant than other southern pines. Longleaf pine characteristically stays in the "grass stage" until its root system gets established. When roots become extensive, the tree begins to grow in height very quickly through the vulnerable years when it is small enough to be engulfed in a ground fire. Tall trees do not have lower branches-they hold their needles high from ground fires and their thick bark insulates the tree trunk from the heat of a fire.
Challenge \#9: Pine trees can be identified by a variety of characteristics, including their bark, their form, and their cones. One of the easiest things to notice, however, is their needles. As this chart shows, however, needle length varies - and sometimes needle numbers vary, too!

Challenge \#10: The three trees featured here are easily found across Florida and are a part of Florida's history and uniqueness. Encourage your 4-H'er to find out more about these special trees.

Materials Needed: Crayons 


\section{Trees and Me Leader's Notes}

The second project book in this series was designed for elementary-aged youth to use while working independently or with a group. The questions at the end of each activity help guide the youngster to reflect on the activity and to apply concepts to their world. Although we believe youth can manage each activity on his or her own, club leaders and project helpers may appreciate the following additional information and teaching tips for each activity. In addition, teachers may wish to use these Florida-specific exercises to complement Project Learning Tree activities with their elementary class. Relevant PLT activities are listed for each activity. Relax and enjoy the natural world along with the kids!

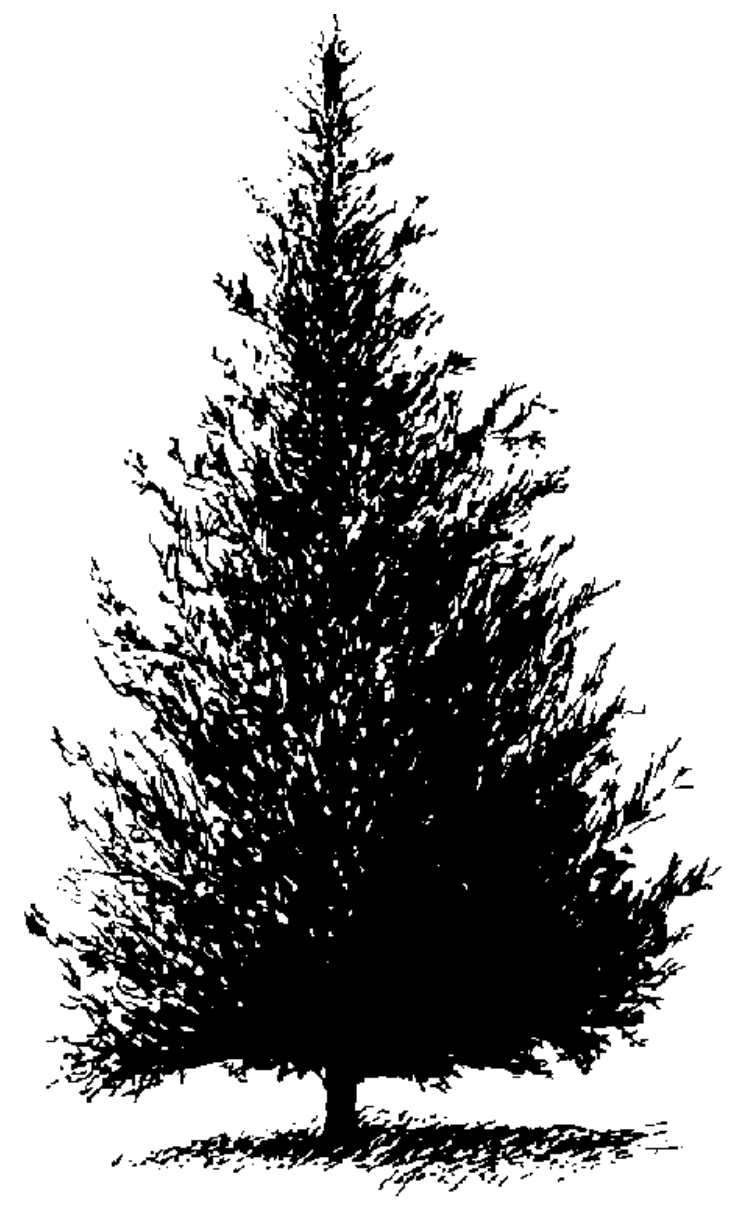

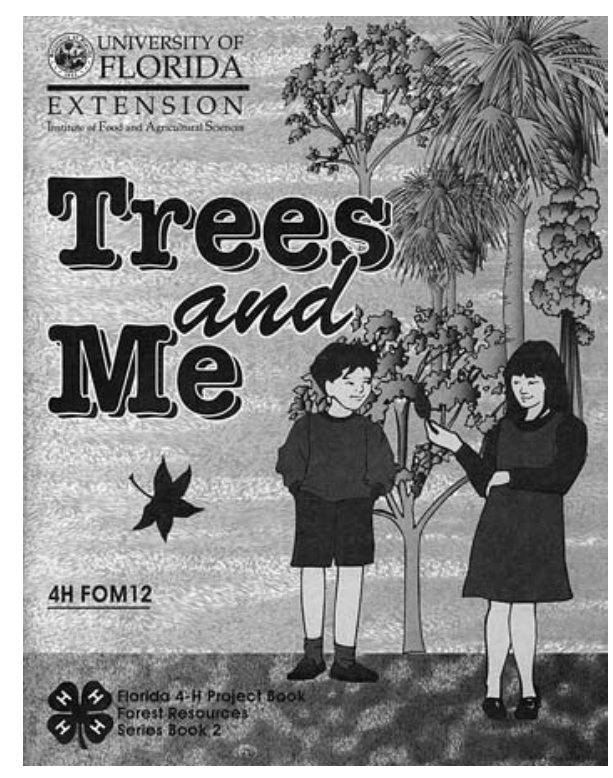




\section{Chapter 1: Tree Basics}

\section{Activity 1.1: What's a Tree?}

\section{Life Skill: Learning to learn Project Skill: Defining the word 'tree' What to Do: Compare a definition that your 4-H'er creates with other definitions.}

Sometimes the easiest questions have the hardest answers. At the most basic level, a tree is a woody plant usually with one central independent stem that grows over 15 feet tall when mature. Plants from many different families can make wood, but if they are shrubs, or too short, they aren't trees. Bamboo is tricky; it does not have buds at the tips of the branches like trees and is considered a woody grass. A palm tree, even though the wood is not heavily used for commercial purposes, is a prized tree in Florida's urban forest--the cabbage palm is our state tree! A strangler fig starts out as vine that sends roots and shoots around trees from the upper branches, eventually engulfing the tree and developing its own, independent root system. Most people don't spend as much time thinking about this as a botanist does. A tree is a tree; people can recognize one when they see it.
Challenge \#1:

Idioms, or sayings, are part of our culture. If your community includes several cultures, explore their tree-sayings. In most languages, there are sayings about animals, too (e.g., busy as a bee, sly as a fox).

Challenge \#2: Depending on their experiences, and knowledge, people may define a tree in varying ways. Ornamental plants and palms might not be considered trees but are important components of the urban forest. Encourage youth to ask other people about their definitions of trees, too.

PLT Connection: In Activity \# 5, PoetTree, youth write poems about trees and other aspects of nature. Activity \#79, Tree Lifecycle, gives a good overview of one tree's life from seed to dead tree, and invites everyone to learn more about a tree's role in an ecosystem. 


\section{Discussion Question Clues:}

The most important characteristics of a tree are: 1) the usual single independent main stem or trunk, 2) presence of wood, and 3) height. The flowers, fruits, leaves, needles, and bark vary too much to be used in a helpful definition.

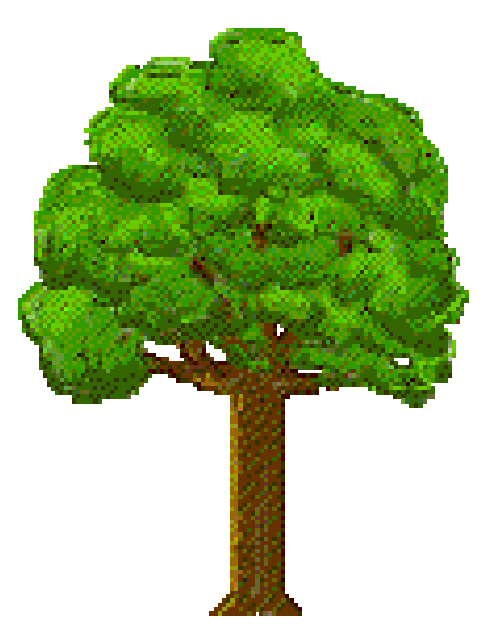

Materials Needed: dictionary, science book, and tree identification book

Forest Resource Box: Use the tree identification book in the box to explore different trees in the eastern United States. Are they all over 15 feet tall when they are fullgrown? 


\section{Activity 1.2: \\ Food Factories}

\section{Life Skill: Applying science process skills Project Skill: Conducting an experiment What to Do: Experiment with photosynthesis}

These two experiments are designed to help youngsters learn more about the internal workings of plants. The action occurs in the leaves, and the rest of the plant helps serve the needs of and benefits from these photosynthesizing organs. Like the suction on a straw, the leaves pull water from the roots, through the sapwood, to the leaves where they can perform their famous magic act: turning carbon dioxide and water into food energy and oxygen. In the experiment, Drinking Plants, your 4-H'er will watch as water, dyed with food coloring, travels up the stem of the celery stalk and into the leaves. The leaves should show the food coloring in less than hour, but if this does not occur, wait longer and the color will eventually reach the leaves. Red food coloring may be substituted for the blue color.

Of course the phrase, "in the presence of sunlight," means a lot. The sunlight energizes the chloroplasts in the leaf, starting the chemical reaction known as photosynthesis. Without the sun, the chloroplasts lose their green appearance and fade out. In the experiment, It's a Cover-up, cover the leaves with cardboard (tin foil will also work) and after about four to seven days, remove the cardboard and compare the covered leaves to leaves that have been exposed to sunlight. You should see a difference in the color of the leaves, demonstrating the chloroplasts' need for sunlight. Even the length of days causes the color of leaves to change. Short days in the fall cause many leaves to turn from green to yellow or red.
Challenge \#3:

Posters are a good way

for youngsters to communicate their knowledge graphically. Presenting this information is good practice for public speaking. Encourage them to do the research, prepare, and develop a wellorganized presentation.

Challenge \# 4: A variety of field trip ideas will help bring this project to life and help emphasize career possibilities. Encourage your field-trip guide to discuss the types of jobs people have at the nursery or greenhouse as they explain how trees grow!

Challenge \#5: The Greenhouse Effect refers to the theory that a rise in carbon dioxide levels and other gases in the atmosphere are apparently due to the increased burning of fossil fuels on earth. Scientists suggest that these gases trap the sun's energy close to the Earth, much like the windows on a closed-up car trap heat inside the car on a sunny day. The increased temperature and increased levels of carbon dioxide may be 


\section{Discussion Question Clues:}

By knowing how fast water moved through a celery leaf, ask your 4-H'er to calculate how fast the water might reach the top of a tree. This assumes that a celery stalk, severed from its roots, is as good a water transporter as a living tree, which may not be true! Plants are primary producers as most animals are dependent on plants as a source of food or their secondary food sources. Plants are thus at the foundation of the food chain because they convert the sun's energy to leaves, stems, roots, and fruit that animals eat for energy. There are some exceptions to this rule, however. Some microorganisms live in caves, sulfur vents, the ocean floor, and ice sheets without access to the sun. They convert other chemicals to energy at the bottom of their respective food chains. If your youngsters are PBS-watchers, they may know a lot about these new discoveries that expand on older understandings of the natural world.

The stomata and leaves actually have several design features that allow leaves to conserve water. Some leaves are thick and waxy (bay, magnolia, and holly), some reduce the leaf surface area (compare pine needles and a sweetgum leaf), and stomata can swell shut during the night to reduce gas exchange.

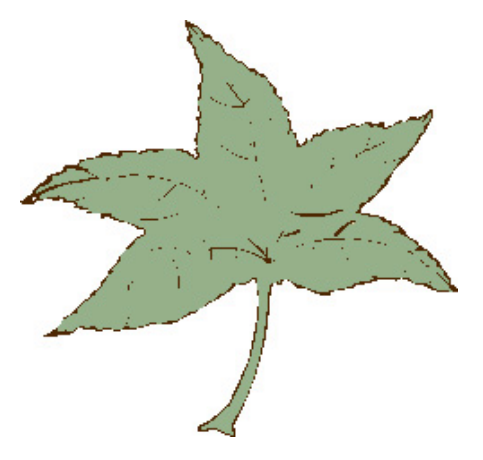

good for some things, and may be bad for others.

\section{PLT Connection:}

Activity \#28, Air

Plants, explores photosynthesis and how this process relates to humans' need for oxygen. Activity \#42,

\section{Sunlight and} Shades of Green, provides an exercise that is quite similar to It's a Cover-up where leaves are covered by cardboard or paper.

Materials Needed: celery, glasses, food coloring, measuring cup, paper towels, vegetable peeler, ruler, scissors, cardboard, paper clips, and string

\section{Forest Resource} Box: A bottle of red food coloring can be found in your box for Experiment 1: Drinking Plants. 


\section{Activity 1.3: How Wood You Like That?}

\section{Life Skill: Problem solving Project Skill: Applying given information What to Do: Answer questions and label pictures about tree trunks}

Wood is such a common component in our lives that we might take it for granted. In this activity, youngsters have an opportunity to think about how wood is made and why wooden products look as they do. An annual ring is made up of light and dark wood. The light wood is produced when the tree is growing quickly and the cells tend to be larger and less strong. The dark wood is denser and is made when the tree grows slowly during times of stress, such as when it is too hot or too cold.

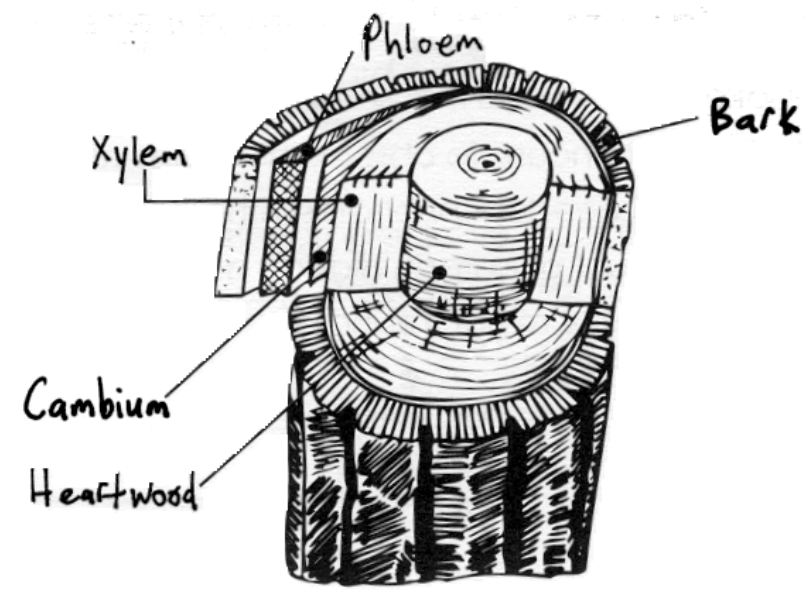

The knot in the wood on page 13 marks where a branch grew, fell off, and was covered by the growing tree trunk. Many mature forest trees have very few branches near the ground, but they all had branches when they were younger. All of those branches left knots inside the tree.

You can read the history of a tree through the annual growth rings. On page 13, the tree on the left grew very quickly for 6 years. It went through some stressful period for 3 years. The tree on the right was scarred by fire at age 6 .
Challenge \#6:

Lumberyards and sawmills are educational places, if everyone is careful, follows instructions, and stays in safe areas. These are large operations, with heavy equipment and machinery moving from place to place. A tour of either, however, could be a wonderful opportunity to see how trees are converted into the variety of types of lumber that people use.

Challenge \#7: Buds at the tips of every branch contain new growth: stem, leaves, and flowers. Buds can also be found at the base of leaves on twigs. After a shoot tip is damaged, trees develop new buds so the process of growth can continue.

PLT Connection: Activity \#63, Tree Factory, introduces the parts of a tree and has youth act out roles to form a living tree. Activity \#76, Tree Cookies, involves the examination of cross sections of trees.

Forest Resource Box: A set of tree cookies are in the box that can be used for several 
different things. Ask each youngster to count the rings, describe what the rings reveal about the tree's history, look for a branch, and look for a knot. The pieces of wood in your box might have knots, too.

Of course all of these age estimates are for the wood at this height along the tree trunk. If this cross section is at the ground level, then we can be assured that the number of years is close to the age of the tree. If this cross section is 20 feet above the ground, the tree had to grow 20 feet tall before its life story could be recorded in these rings.

\section{Discussion Question Clues:}

The youngest part of the cross-section of a tree is closest to the cambium layer. Older parts are at the center of the tree and the outside layer of its bark. People who visualize things easily may be able to mentally convert a tree trunk to a piece of wood and explain how annual rings are located on the boards. The drawing on the right may help.

Some people think wood with knots is less desirable, and others like the look of knots in wood. Some trees drop their lower branches, called self-pruning, and grow around the knots, making more valuable wood. Other trees are pruned by people to produce the same effect.

Much of a trunk on a large tree is actually dead wood. The layers of the heartwood are made up of dead cells. Some trees can still live if a portion of the bark is torn off or the center is hollow for example. As long as the cambium layer is intact in enough of the tree, it can live. The cambium is the vital part of the tree. A tree can be killed by girdling it-making a thin cut into the sapwood all the way around.

Fast growing, light-colored wood is less dense and weaker than slow-growing wood in a narrow annual ring. Some trees have been cultivated to grow very quickly but this wood may not have the strength equal to that of slow-growing trees. Fastgrowing trees are often converted to pulp.
The study of tree rings is called dendrochronology. By identifying the years of drought or fire, fossil tree rings can be lined up to tell a story about global climate changes.

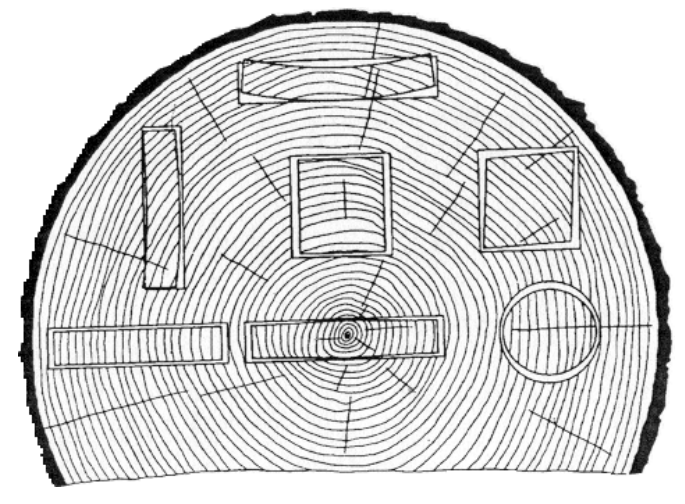




\section{Chapter 2: Getting to Know Florida}

\section{Activity 2.1: Tree Traits}

\section{Life Skill: Learning to learn Project Skill: Observing characteristics of trees \\ What to Do: Go on a scavenger hunt}

The ability to identify trees is really all about becoming familiar with the characteristics that make trees different. This activity points out some of those characteristics and asks youngsters to hunt for trees and leaves that have these attributes. These characteristics are also used in the next activity--to identify 18 major trees in Florida.

\section{Discussion Question Clues:}

A deciduous tree is one that drops all of its leaves at one time each year. In many areas of the country, including parts of Florida, this happens in the fall. In other parts of the country, such as south Florida, some trees keep their leaves through winter and drop them as new leaves emerge in the springtime. Leaves on the same tree may be different sizes due to insect damage or exposure to sunlight (shaded leaves are often much larger than leaves that get lots of sun). Leaves on some trees can develop into several different shapes as they grow (like sassafras and mulberry).
Challenge \#8: Public parks, school campuses, nature centers, and even parking lots are places where the landowner may agree to label the trees. A brochure or a map could be used if labels are not possible.

\section{PLT connection:} Activity \#64, Looking at Leaves, engages a group in comparing, contrasting, classifying, and categorizing leaves.

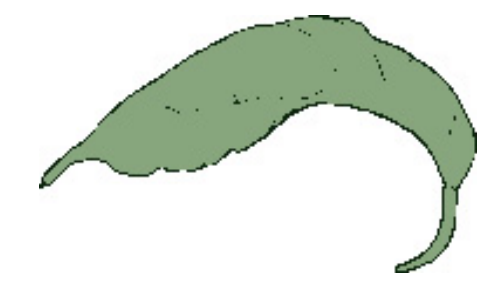




\section{Activity 2.2: \\ The Key to Trees}

\section{Life Skill: Making decisions Project Skill: Learning to use a key What to Do: Find as many of the trees on the Tree ID cards as possible}

This activity invites youngsters to learn to use a key and provides them with tree identification cards. The challenge is that the cards do not have the tree name on them; that's what the key is for! The key (on page 19) can be used to identify the characteristics of the trees. Most of these characteristics are described on the back of the card; some can be observed from the leaf images. Below are the answers to check your budding tree identification experts.

\begin{tabular}{|c|c|c|}
\hline Leaf Position & Tree Name & Ecosystem \\
\hline $\begin{array}{l}\text { Page } 23 \\
\text { Top left box } \\
\text { hardwood }\end{array}$ & Water Oak & Bottomland \\
\hline Top right box & Gumbo Limbo & Tropical hammock \\
\hline Middle left box & Black Mangrove & Mangrove swamp \\
\hline Middle right box & Turkey Oak & Sandhill \\
\hline Lower left box & Swamp Tupelo & Swamp \\
\hline Lower right box & White Mangrove & Mangrove swamp \\
\hline $\begin{array}{l}\text { Page } 25 \\
\text { Top left box } \\
\text { hardwood }\end{array}$ & Live Oak & Bottomland \\
\hline Top right box & Sweetgum & Upland hardwood \\
\hline Middle left box & Slash Pine & Flatwoods \\
\hline Middle right box & Longleaf Pine & Sandhill \& Flatwood \\
\hline Lower left box & Southern Magnolia & Upland hardwood \\
\hline Lower right box & Pignut Hickory & Upland hardwood \\
\hline $\begin{array}{l}\text { Page } 27 \\
\text { Top left box } \\
\text { hardwood }\end{array}$ & Red Maple & Bottomland \\
\hline Top right box & Laurel Oak & Upland hardwood \\
\hline Middle left box & Baldcypress & Swamp \\
\hline Middle right box & Pigeon Plum & Tropical hammock \\
\hline Lower left box & Sand Pine & Scrub \\
\hline Lower right box & Red Mangrove & Mangrove swamp \\
\hline
\end{tabular}


To sort the cards and use the key, make copies of both sides of the cards. Make absolutely sure you copy the proper information on the back of the right leaves! You can make one-sided tree cards, too - with the leaves on one side and blank pages on the back. These cards can be used to play a variety of card games, like Concentration (with 2 sets) or Fish (with 3 or 4 sets each on different colored paper).

\section{Discussion Question Clues:}

Tree names help people know what they are talking about when the trees aren't right there. Sometimes it is difficult to tell one species from another, and then experts don't know which name to give the tree in question! Common tree names may vary from one region of the country to another, and that is why each tree also has a scientific name--the official name that refers to that species in every language. Perhaps some of your 4-H'ers would like to learn the scientific names and the common names of nearby trees.

Keys can be developed for most any set of items: books on the shelf, kids in the group, soda pop in the store, or butterflies in Florida. It is important to have a known population before you begin, and then work to divide the population into two groups, then each group in two, etc. Each question should be answered by yes or no, without ambiguity. Key-making is good practice in critical thinking and problem solving.
Challenges \#9: A field guide will be a helpful resource for making more tree cards. Youngsters may wish to write clues or poems on the back and quiz others!

Challenges \# 10: One way to teach others how to do something new is to give a demonstration. Remind your 4-H'er that the key to a good demonstration is thoroughly knowing the topic and practicing the presentation.

PLT Connection: In Activity \#68, Name that Tree, students use leaf margins, leaf arrangement, buds and twigs, fruit and flowers, bark, and tree shape to identify trees.

Materials Needed: double-sided copies of pages 23-28 (NOTE: When you copy pages 23-28, make sure you line up the edges of cards.)

\section{Forest Resource}

Box: The box contains one set of laminated tree identification cards. 


\section{Activity 2.3: \\ A Tree's Favorite Place}

\section{Life Skill: Making decisions Project Skill: Applying information What to Do: Match the trees with their favorite ecosystem}

Florida is a large state that covers many climatic zones, soil types, and water conditions. These three factors greatly determine the types of plants that can grow in Florida. An association of plants that prefers a certain set of conditions, and reproduces itself in these conditions, helps create a specific ecosystem. Some scientists say Florida has over 20 different natural ecosystems, but we have lumped them together to form eight distinctly different, important forest ecosystems. You can visit state parks and forests throughout Florida to see these ecosystems (see page 33 in Trees and Me).

\section{Discussion Question Clues:}

Across Florida, development impacts forest ecosystems. In some parts of Florida, very little native forest is left. The region has become homes, office buildings, shopping malls, and roads. In ecosystems where water levels are critical, too much water or too little water could also be a problem. For example, rising sea levels are thought to be altering coastal hammocks along Levy County and other areas. Florida is also home to a large number of invasive exotic plants and animals. Once they enter an ecosystem, they may change the way the ecosystem operates, like melaleuca in South Florida.

To determine the dominant ecosystem in your area, you need to figure out what type of forest ecosystem is most common. The soil and climatic characteristics of an area have a lot to do with what type of forest ecosystem will develop there.

If the area is already developed or cleared for farming, the soils, latitude, and moisture levels of

\section{Challenge \#11:}

Booklets are a good way to provide textual information accompanied by illustrations and photographs. Several websites provide good information about Florida's ecosystems. Direct your 4-H'er to: the 4-H Forest Ecology Website at www.sfrc.ufl.edu/4h and Florida Ecosystems information at http://www.ficus.usf.e du/docs/fl_ecosystem/ florida.htm.

Challenge \#12: When making a poster, make sure that your 4-H'er checks for misspellings in the poster text, that the text can be easily read, and that both the text and illustrations are an appropriate size (not too big or too small). Use the websites listed in Challenge \#11 above.

\section{PLT Connection:}

Activity \#20, Environmental Exchange Box, is a chance for youth to explore another ecosystem by swapping artifacts by mail. By jumping across the Caribbean Sea, Florida youth can explore the 
that area will have to be used to determine what type of forest used to grow there. Some old remnant trees from the original forest might still remain. Your county forester, urban forester, city arborist, or Extension agent may also be able to provide information on what types of ecosystems used to be or still are common in your area.

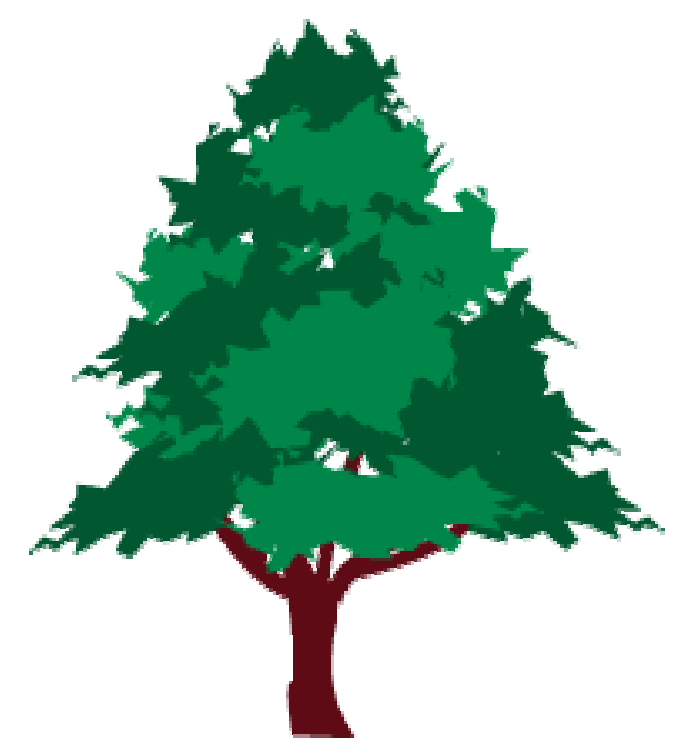

forest ecosystems of Puerto Rico in Rain

Reasons, Activity \#29. Activity \#45, Web of Life, helps youngsters draw a mural to explore the animal and plant life that is dependent upon one particular forest ecosystem. Activity \#48 suggests that the group compare and contrast physical and biological differences in three different ecosystems: Field, Forest and Stream.

\section{Forest Resource}

Box: Check out the box for a map of the ecosystems of Florida. Ask the group to locate where they live and help discover all the forest ecosystems in their county. 


\section{Activity 2.4: City Trees}

\section{Life Skill: Making decisions Project Skill: Choosing an urban tree for a site What to Do: Select and plant a tree in an urban area}

Many communities in Florida have beautified their urban environment with trees. Some of these trees normally grow in the area, but the rest have been imported from other ecosystems. Some cities even have ordinances and requirements that protect existing trees, especially large trees and live oaks. Have your 4-H'er think about school sites, parks, highway edges, residential streets, and other public lands in the community and ask if there is a planting plan. Where would shade be desired--at a bus stop? Help your 4-H'er use the planting guide and the list of species on page 35 of Trees and Me to choose a tree that is appropriate for your region and the specific requirements of the site. Remember to ask your County Extension agent, local forester, or a Master Gardener for assistance and advice.

Make sure the newly planted tree gets the right amount of water, nutrients, and other essential ingredients so it has a long life. These amounts will depend on time of year, region you live in, and what type of tree you and your 4-H'er plant.

\section{Discussion Question Clues:}

Urban forests provide many benefits: shade; homes and food for animals like birds, insects, lizards, and squirrels; soil stabilization; noise reduction; filter for air pollution; and reduction in stormwater flow. Individual trees may be prized for enhanced property value, beauty, climbing potential, and swings.

Have your 4-H'er find out if your community has a tree ordinance, incentives to plant trees, or tree give-aways where community members can pick up free seedlings. If so, how do these programs help protect trees? Challenge \# 13: Your local parks department, urban forester, or city arborist may have a long list of ways your group could help improve or maintain the urban forest. Your group could help plant an area, water recently planted trees, teach people to value city trees, search for insect pests, redirect trails that compact tree roots, etc. 4-H'ers could also join existing groups and treeplanting activities and lend a hand.

\section{PLT connection:} Activity \# 30, Three Cheers for Trees, helps youth identify the benefits of trees in public places. In Activity \#31, Plant a Tree, youth can participate in a treeplanting program in their community... or start one. 


\section{Activity 2.5: \\ Guide the Way}

\section{Life Skill: Communicating with others Project Skill: Teaching people about a natural area What to Do: Create a trail guide for a natural area}

Self-guided trails are popular ways to learn more about our surroundings. Many state and local parks have trail guides-either informational signs or brochures-that enable the visitor to identify trees, appreciate the local history, and pay attention to the environment. Help your 4-H'er choose an appropriate area to develop the interpretive portion of a trail. Ideally, the trail itself will already exist, and she or he will not have to cut brush or trim branches. If the area is welltraveled but is not a "trail," like a backyard or a city park, you can help your 4-H'er map the area, identify interesting features, and create a trail. Rather than physically marking a trail on public property, a map that identifies the key areas may be more appropriate. Make sure the landowner is contacted before this project gets underway, that everyone has permission to design and interpret the trail, and that there are no liability or safety concerns.

A good nature trail has something to say to the users that they might not know. Encourage your 4H'er to investigate the ecosystem represented on this property and teach visitors about how the system works, how the land was used before, or what types of trees are growing there.

\section{Challenge \#14:}

Interpretive trails at existing parks or nature centers vary enormously. They may unfold like a mystery, gathering clues along the way. They may focus on history or seasonal change. They may identify plants and signs of animals, or concepts like succession and forest health. They should all be entertaining, engaging, and lead the visitor to notice more things.

PLT Connection: In Activity \# 47, Are

\section{Vacant Lots}

Vacant?, youth can look closely at the plants and animals that thrive in an undeveloped landscape. Earth Manners, Activity \#87, instructs youth in ways to cultivate respect for living things and their habitats. 


\section{Discussion Question Clues:}

Most people find that the experience of learning the names and natural history of plants and animals helps them appreciate these things more. They may notice the specific plants or birds more often, once they are identified, and feel a stronger sense of kinship or pleasure. A walk in the woods may be more like visiting old friends!

If this exercise evolves into a significant activity and useful product, help your 4-H'er make this trail more widely known. Perhaps the community's park department could erect a sign to inform visitors, or print a brochure for distribution. If the trail is on school grounds, perhaps teachers and other classes could use the area as an outdoor laboratory.

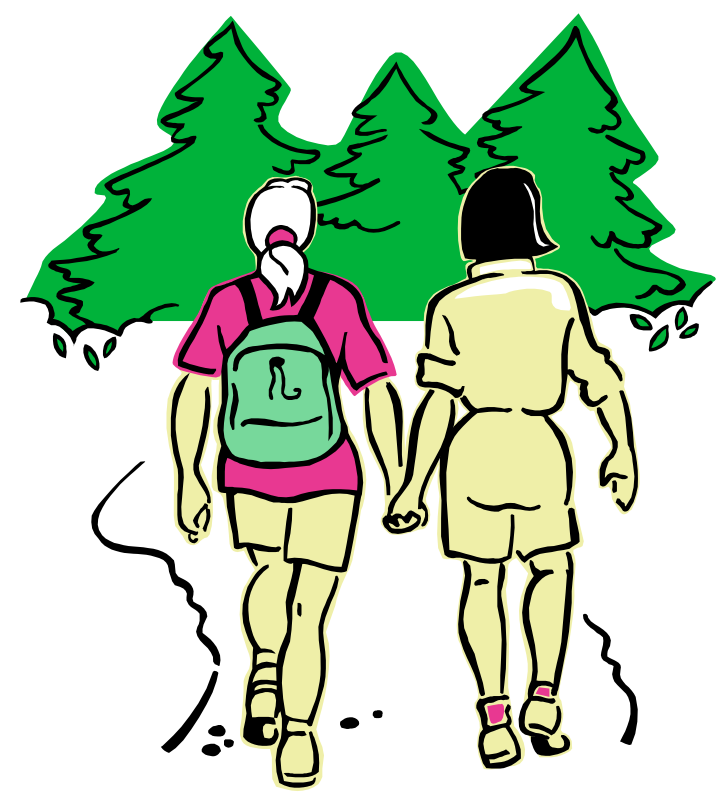




\section{Chapter 3: Gifts from Trees}

\section{Activity 3.1: Wood is Good}

\section{Life Skill: Learning to learn Project Skill: Combining experience and knowledge What to Do: Determine the properties of wood products in your 4-H'er's home}

This activity focuses on wood and helps youngsters learn more about how it is made by trees. To help youth understand the wide variety of lumber and wood products available, take a field trip to a lumberyard or home improvement store. Search for plywood, chipboard (also called particleboard), oriented strand board (OSB), and solid wood and if you need help identifying these products, ask someone who works there for guidance. Compare 4-ply plywood to other types of plywood. Help your youngsters look at several sides of a 2x4 and determine what part of the tree it came from. In the furniture or kitchen cabinet section, ask to see a product made of chipboard that is covered with veneer.

It should be easy to find wood and paper around the house. These common forest products are everywhere in our lives. It could be tricky to know which parts of the home or furniture are solid wood. Guide your 4-H'er to look inside the cabinet, under the table, and at the edge of the door. Look for glue lines, separation marks, or places where the grain doesn't match to figure out if it is one solid piece or several pieces joined together. Once youth have identified some solid wood products, help them look for the annual rings and imagine how it grew.

Pine plantations in Florida provide a great deal of wood fiber for the pulp and timber markets. The forest products and paper companies produce $\$ 9$ billion annually in manufactured products in Florida. The forest industry depends upon the
Challenge \#15: While visiting the lumberyard or home improvement store, ask the salesperson if there are unneeded pieces of lumber, OSB, chipboard, and plywood.

Challenge \#16: New homes typically have plywood subflooring, studs covered with plywood or OSB sheathing, laminated lumber or oriented strand board beams, joists supporting the floor, trusses holding up the roof, and lots of other wood.

Challenge \# 17: Woodworking is a fun hobby and a very useful craft. Contact your county agent for these project books.

\section{Forest Resource Box: Your box includes samples of solid wood (2x4), chipboard, oriented strand board, and plywood.}


nearly 14 million acres of forestland of which about 5 million acres are in plantations. The forest products industry provides over 60,000 jobs in Florida, and forest product manufacturers provide employment for another 72,000 people. When traveling across central and northern Florida, you may see rows of planted pine trees. This land may be owned by anyone: a timber company, a pension fund manager, a bank, an investment partnership, or a regular family. They are managing the land to efficiently produce wood fiber that may eventually become our cereal boxes, wood framing, kitchen cabinets, toilet paper, or even more!

\section{Discussion Question Clues:}

To help your 4-H'er "see" how trees grow, try taking a piece of newspaper and roll it up loosely to represent the annual growth rings. From the end, the cross-section view shows all the years tightly pushed together. If a board were cut out of a tree trunk, the view from the "end" would show concentric circles of annual growth rings. If the wood is viewed along its length, the annual rings may show as narrow long stripes, long triangles, or broad, fat strips. If the wood were peeled off the tree for veneer, the sheet of paper-thin wood would unroll to a large flat piece, as it was before it was rolled up. It may be hard to see annual growth rings in veneer. The broad bands on plywood are annual rings. The illustration on the right may help you visualize this.

Wood has a natural, earthy quality to it. It has excellent thermal properties that help insulate us from temperature extremes, and is recyclable and renewable. The properties we value in trees when it comes to wood might relate to workability with common hand tools, color, strength, grain pattern, straightness, and its abundance as a renewable resource. Someday we might have square trees for lumber, or perfectly round trees for veneer! 


\section{Activity 3.2: Incredible Edibles}

\section{Life Skill: Leading Self and Others Project Skill: Identifying tree products What to Do: Make food from trees and share with friends and family}

Tree fruits and edible tree products provide flavor and nutrients in our food. They are everywhere, once you start looking for them. These recipes use some tree edibles that are probably in your kitchen.

\section{Discussion Question Clues:}

It may be difficult to find out where produce originated, and even harder to know where canned or frozen fruit was grown. Pine nuts are one tree product that is still harvested from the wild. Most tree fruits are cultivated in orchards or groves. Pecan is a nut that is grown in Florida. Some Florida tree fruits travel to other parts of the United States (mangoes, oranges) and some are used locally (key limes). Some states grow certain foods in seasons when we can't. Apples and cherries, for example, require cold weather to set the buds; these trees do a poor job of producing fruit in Florida. Our mild climate, lack of frost (in the south), and rainfall enable certain trees to do very well here. Honey is a prized product from many forests. Tupelo honey comes from the tupelo gum tree. Palmetto, sourwood, gallberry, and titi are other forest plants that provide nectar for honey.

Weather, insects, transportation concerns, and diseases may make some crops fail and others flourish. Soft fruit that ripens quickly usually doesn't travel well, so is consumed locally. If a large part of the crop is destroyed by a hurricane, for example, a shortage will cause the price of the remaining fruits to rise. While one grower may suffer, another may make a healthy profit.
Challenge \#18: On a trip to a grocery store, encourage your 4-H'er to take good notes about the fruits he or she finds. Remember to look beyond the produce section, in canned foods, frozen foods, dried fruits, candy, and the baking section. Here are a few tree fruits that may be missed: avocado, date, nutmeg, coconut, apricot, all citrus, all nuts, and quince. There are some tree products that are not from fruits: cinnamon is from bark and chocolate and coffee are from seeds (which are found inside fruits). There are many fruits in the stores that are not from trees, so this activity may take a bit of research. Blueberries, blackberries, and raspberries are from shrubs not trees. Grapes, passion fruit, and kiwi are from vines. Strawberries and pineapples are fruits from non-woody plants.

Challenge \#19: It may be difficult to find a main dish or vegetable that comes from trees. Think about ways tree products enhance an entrée: cashew chicken 


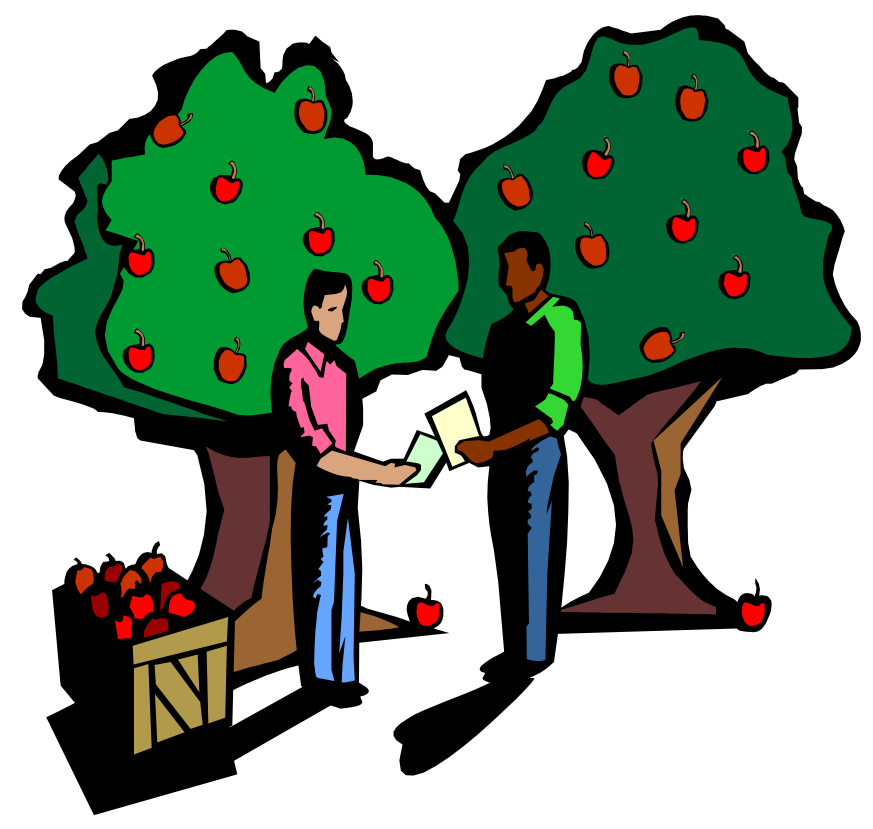

with orange sauce, or green beans with almonds. Use the next activity to add salad dressing and ice cream to the menu!

PLT Connection: In Activity \#16, Pass the Plants Please, students consider the plants (not necessarily trees) that they have eaten in the last week.

\section{Forest Resource} Box: A can of fruit, cinnamon, and pecans are in the box for this activity. 


\section{Activity 3.3: \\ Tree Surprises}

\section{Life Skill: Communicating with others Project Skill: Conducting a survey What to Do: Find 5 people and give them a 'tree quiz'}

There are probably things in your home that you don't realize are made from trees. The industry of extracting chemicals from trees and pulp has grown enormously, and far exceeds what most folks know. This activity reveals a few ingredients that make some common household products. By inviting other friends to test their knowledge, this activity helps raise awareness of the many treerelated products in our lives.

Many flavoring ingredients come from the gums extracted during pulping. Almost all peppermint, lime, and related flavors for candies come from this source. Artificial vanilla flavoring is made from lignin from pine trees.

\section{Discussion Question Clues:}

Most of the time we don't really know how products are made or what goes into them. Most of the time it probably doesn't matter. But all of these products represent chemical and mechanical engineering careers to which some youngsters might aspire. And when issues of forest management arise in the community news, it might be useful to know how dependent we are on Florida's pine plantations for things that aren't wood or paper.
Challenge \# 20: A careful reading of labels in the grocery store or at home in the kitchen will reveal a variety of plant-based additives. Not all come from trees. Encourage your $4-\mathrm{H}^{\prime} \mathrm{er}$ to research the sources of any questionable ingredients. The information on page 50 in Trees and Me is a good start.

PLT Connection: In both Activities \#12, Tree Treasures, and \#13, We All Need Trees, youth explore the many different products that come from trees. Activity \#12 is more of a brainstorm and "did you know?" exercise; Activity \#13 helps youth understand how these products come from trees.

\section{Forest Resource} Box: The box contains a bag of products for this activity made from cellulose, cellulose gum, spun cellulose, wood, paper, latex, and cork. 


\section{Activity 3.4: \\ Paper Pieces}

\section{Life Skill: Leading self and others Project Skill: Recycling paper What to Do: Make paper from scraps}

Many people collect newspaper, office paper, posterboard, and cardboard for recycling. This activity helps youngsters realize how that collected paper is processed and converted back into paper. All paper is made from fiber, but not all of that fiber comes from trees. A fine "rag" paper is made from cotton and new papers may be made from kenaf or banana leaves. Sugarcane bagasse (the fibrous residue leftover after cane sugar is made) and bamboo fibers are used for low grade paper. The vast majority of our paper, however, comes from trees. By re-pulping used paper (in the blender), youngsters can see how the water helps the pulp spread on a screen. Once the water is squeezed out and evaporates away, a piece of "paper" remains.

You can buy paper labeled "recycled content" or "post consumer content." The difference is that only the post consumer percentage is made from paper that was sold, used, and collected for recycling. The other recycled content is usually waste scraps in the paper mill that are cleaned up at the end of the day and dumped back in at the pulping stage; this paper never left the mill. No matter which type of recycled fiber is in your paper, it represents resources that are reused and not thrown away.

The process of making recycled paper can be messy. If you want to do this activity regularly with a group of youngsters, you may wish to devote a blender, rolling pin, towels, and sheets to the cause. Start by having your first group make a set of deckles and follow the steps on pages 52 and 53 in Trees and Me.
Challenge \#21: Additions to the recycled pulp can lead to interesting and beautiful designs in the paper. Creative youth can also make their own deckles to shape their paper into hearts or other designs.

Challenge \# 22: Paper mills are located in northern Florida and southern Georgia. Many of them provide tours and welcome the opportunity to educate visitors about the paper-making process.

Challenge \# 23: Most communities have a facility that collects recycled products from businesses and homes. Items are sorted, graded by quality, and shipped to the recycler. Find out more about this process and if any products come back to your community for sale.

PLT connection: Activity \#51, Make Your Own Paper, is another very similar version of this activity. In Activity \# 83,

Reduce, Reuse, Recycle, youth launch a community recycling program. Activity \# 93, Paper Civilizations,. 


\section{Discussion Question Clues:}

Although it isn't often discussed, it is just as important to buy recycled paper as it is to collect it. In fact, the ability for communities to collect and sell their recycled paper to a mill is limited by the market we create by purchasing recycled materials. Recycled paper fiber ends up in more products than just paper. It goes into egg cartons and cellulose insulation, too.

Recycling reduces the pressure to harvest some forests. Some foresters believe that recycling could hurt some forests by making it uneconomical for a tree farmer to sell pulp trees to the paper mill, even though there are other uses for plantationgrown pines. If someone can't make a living by growing trees, they are likely to do something else with their land. The land may be sold and used for developments. Before proclaiming recycling as always good or always bad, encourage your 4-H'er to research the local situation. Where is the pulp mill that takes recycled paper? Have they expanded capacity, or do they accept less pulp timber as a result? What other options do tree farmers in the vicinity have to sell their products? explores the history of paper-making through various cultures around the world.

Materials Needed: See page 51 of Trees and Me.

\section{Forest Resource}

Box: Two deckles are in the box. You can make more from the directions on page 52

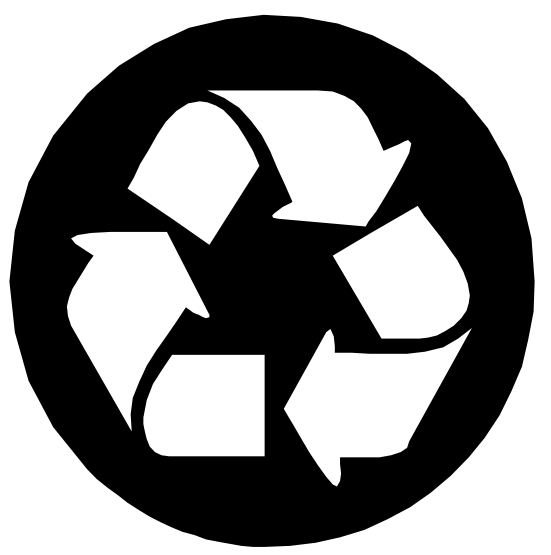




\section{Activity 3.5: \\ A Natural View}

\section{Life Skill: Relating to others \\ Project Skill: Comparing people's opinions What to Do: Take pictures and ask people which they like}

When people make a list of the benefits of forests, they usually include the fact that forests are pleasant, restful, beautiful places. This activity enables youth to look more closely at this aspect of forests. Of course, they may not have easy access to forests, so this activity includes trees, woods, and natural areas of any kind as potentially attractive locations.

As your 4-H'er goes about taking pictures and selecting 10 for this activity, encourage him or her to consider different aspects of the interactions we have with the natural world. Some photographs may be of a view, but others may be of a chair under a tree, for example. What might people be reacting to if they choose one picture and not another? Unpleasant images to one person may not be unpleasant to everyone. A study compared the pictures that urban youth preferred to those preferred by environmentalists. Where the youth found shopping malls, bright lights, and busy scenes more exciting and interesting, the adults preferred trails in the woods! Encourage your 4H'er to take some attractive and interesting pictures of areas without trees-like a city water fountain, a sculpture, or a building.

\section{Discussion Question Clues:}

By taking notes and remembering what people talked about, the 4-H'er should be able to summarize this information into a general perspective of these people's preferences. It is often challenging to accurately compile qualitative data like this, so some guiding questions may be helpful:
Challenges \#24\#25: Visiting several different urban parks can provide youngsters with ideas about what they enjoy, what people use, and what may not be helpful in a new park. Encourage them to think about all the ways people use parks-for Frisbee, walking the dog, enjoying the shade, and playing on swings. Do any of these uses conflict? Should some uses be isolated? Which ones can occur near each other?

\section{PLT connection:}

Activity \# 5 is an opportunity to encourage creativity by writing poems about trees, Poet-Tree, to be exact! In Activity \#30, Three Cheers for Trees, youth reflect on the many benefits of trees in public places.

Materials Needed: Camera 
What did people say was better about these pictures than those? What do these pictures have that the others don't? How many people disagreed with this explanation? Could they say why?

If park managers knew what views people preferred, they might be able to design these into trails, campgrounds, and roadside stops.

Landscape architects who work for the US Forest Service spend a lot of time designing campgrounds, lakesides, trails, and roadways to provide visitors with attractive and interesting landscapes.

It is important for urban areas to have green, natural areas. Small "pocket parks" provide a little shade, a little color, and a little change of scenery from the hard surfaces of sidewalks and buildings. Water is often an important element to city parks, in fountains, streams, or ponds. People find the changing pattern of light and waves interesting to watch, and the sound of flowing water soothing. As urban areas expand, it is important to identify natural areas that can be protected and preserved. It is easier to protect them than to recreate them out of a parking lot!
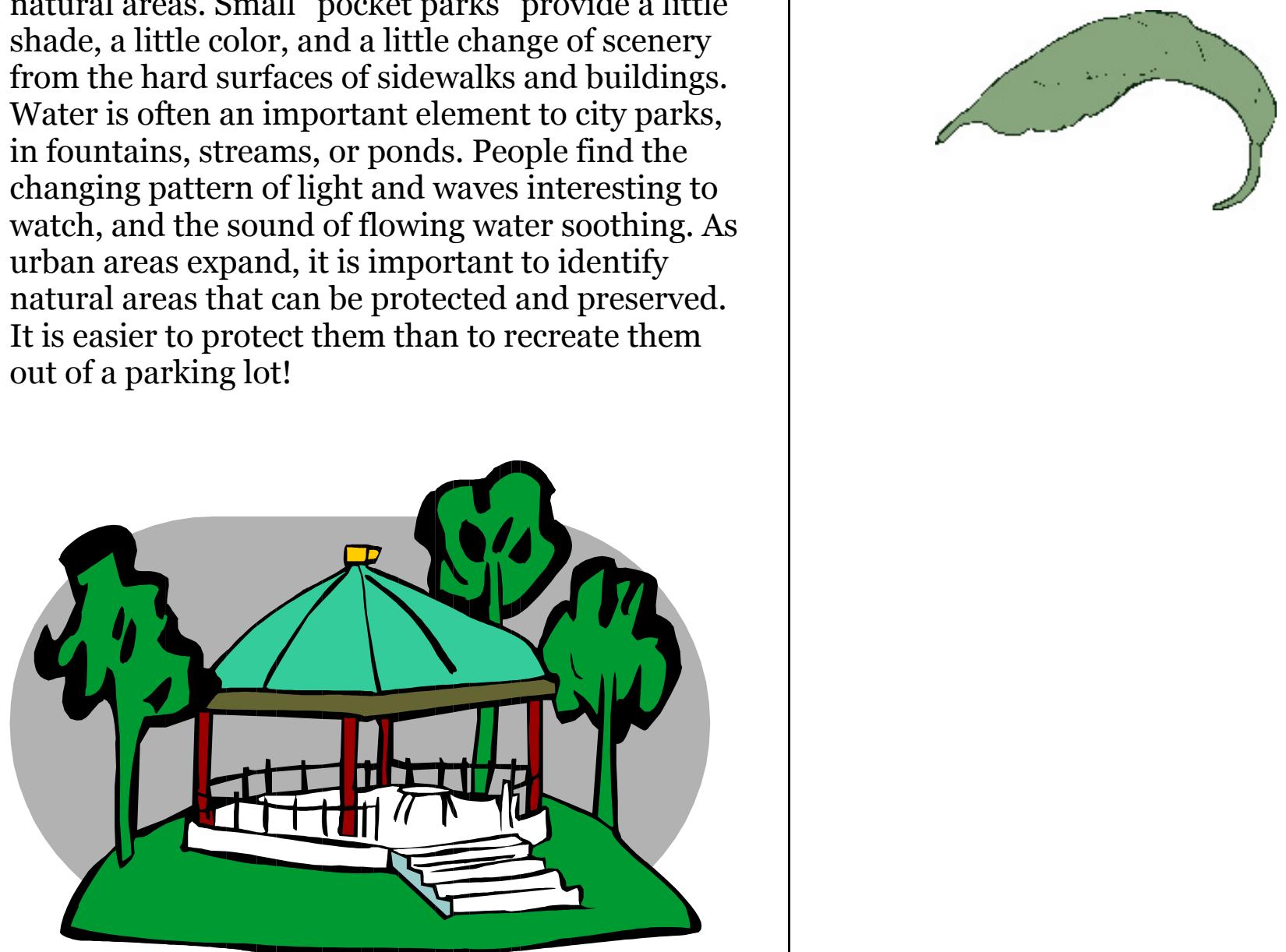


\section{Florida's Fabulous \\ Forests \\ Leader Guide}

This project book was written for older youth, ages 12-16, and therefore it depends on their ability to identify interesting projects, seek information, and create meaningful projects. This project book may be used in its entirety as 15 activities, or youngsters can identify a few projects on which to concentrate their efforts. Each activity and many of the challenges are designed to help your youth practice important life skills while maintaining interest and excitement in Florida's forests.
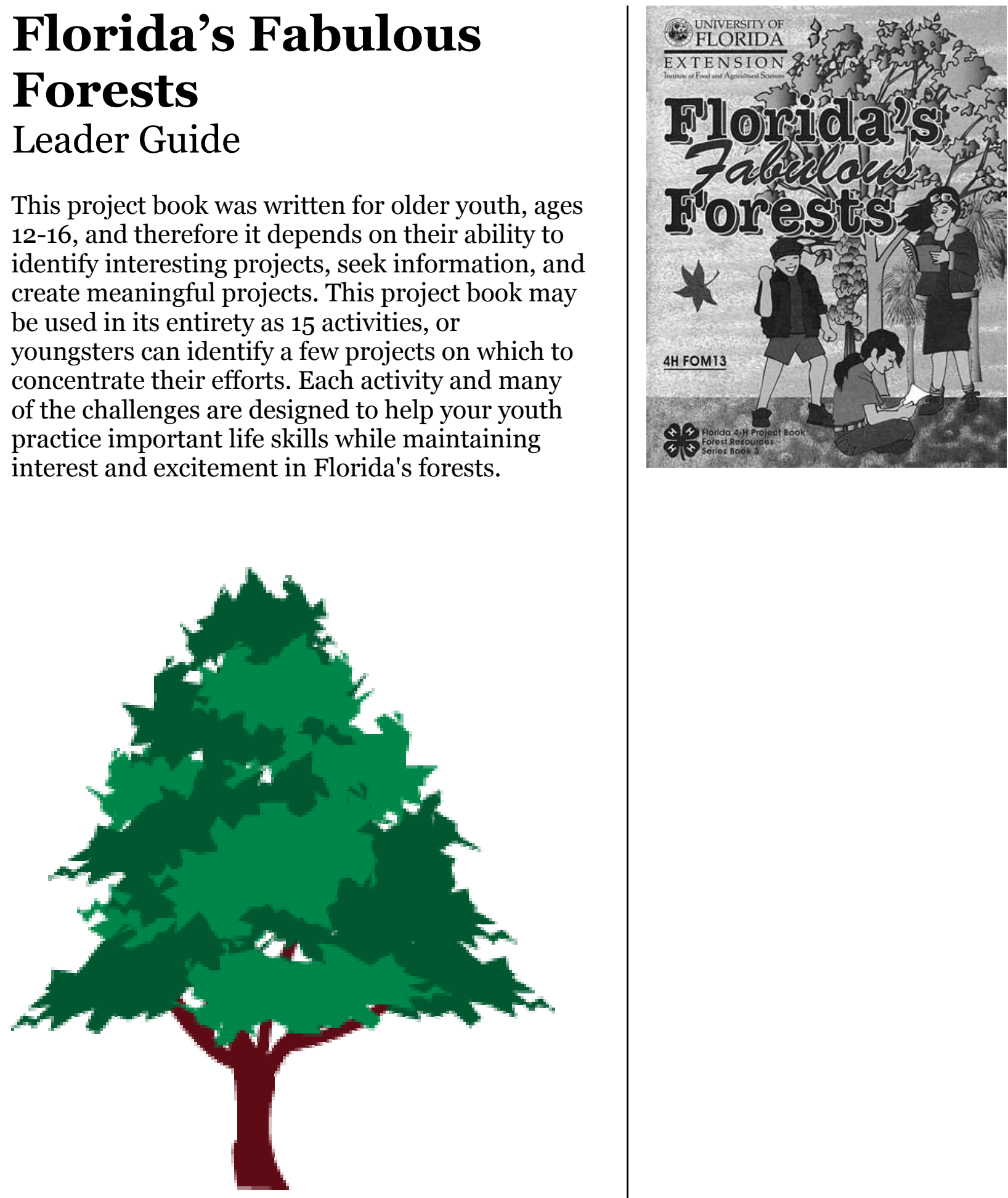


\section{Chapter 1: Introducing the Forests}

\section{Activity 1.1: A Walk in the Woods}

\section{Life Skill: Planning and organizing Project Skill: Assembling a hiking kit What to Do: Determine items needed for a forest hike and make a hiking kit.}

This project book encourages youth to explore Florida's wild areas, and therefore needs to begin with some safety tips for being outside. Most youngsters know about sunscreen and insect repellant, but hikers in our forests should also know how to identify poisonous plants, like poison ivy, what to carry with them in the field, and how to prepare for emergencies. Adults may ask if any youngster is allergic to yellow jacket, bee, or wasp stings and be prepared with appropriate medications. Train everyone to check for ticks after an excursion to the woods.

Youth must remember to pack the right essentials for a hike in the woods, and know why to bring them and how to use them. It is a good idea for youth to practice identifying poisonous plants and venomous snakes before venturing out to a forest. When in doubt, keep your distance.

\section{Discussion Question Clues:}

Respecting a forest involves enjoying it while minimizing the impact on it. This means hikers should not leave anything behind that they take in, not take out anything they find there, and stay on the trail as much as possible so as not to destroy essential parts of the forest system. Modeling good hiking etiquette is the best way for your youth to show others how to behave in the forest. If this subtle message is not sufficient to deter others' inappropriate actions, your youth can point out the consequences of misbehavior to hiking friends. (They should probably not do this for strangers.)
PLT connection: Activity \# 87, Earth Manners, helps youth think about how they should treat the earth and develop slogans for these positive behaviors.

\section{Materials Needed:} Markers, crayons, pens, or pencils, and paper

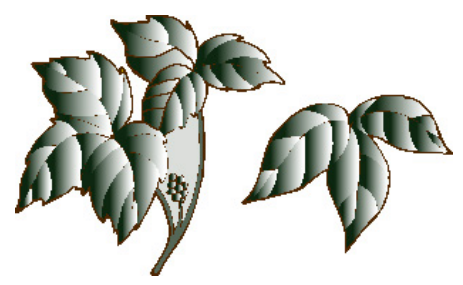


It is important to plan ahead before visiting a forest so that when the unexpected occurs, hikers know what to do and are prepared. This enables youth to deal with an emergency more quickly and effectively. Taking a first aid class before venturing outdoors can offer some degree of preparation for emergencies as well as provide confidence for other outdoor excursions like boating, swimming, camping, canoeing, or climbing.

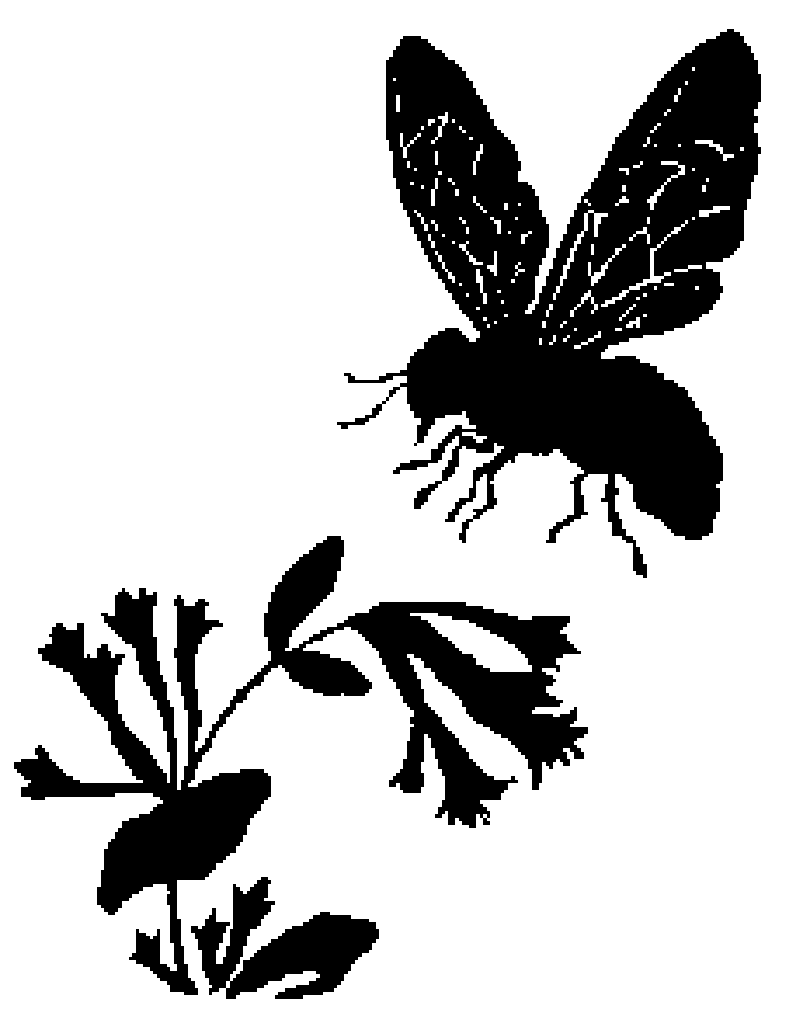




\section{Activity 1.2: So What's a Forest?}

\section{Life Skill: Learning to learn Project Skill: Observing and recording information \\ What to Do: Visit a forest, draw what you see, and reflect on what you learn.}

Some seemingly simple questions, such as this activity title, are actually difficult to answer. Some experts identify forested areas by the amount of tree cover while others describe all the interactions of living and non-living components. All definitions are acceptable, as long as everyone knows what they are talking about. For the rest of this book, we use the basic description of a system dominated by trees in Florida, and include pine plantations and the urban forest.

\section{Discussion Question Clues:}

All forests are alike because they are dominated by trees, have animals and other plants living in them, and are constantly changing. Forests differ in management practices, species composition, density, climate, and other factors. Management objectives and practices can have the most dynamic effects on a forest. For example, plantations that manage trees for pulp can be different from those plantations that manage for veneer and lumber because of the types of trees they grow and when the trees are harvested. Some forests may be managed for all of these products as well as wildlife. Likewise, forests managed for intensive recreation will be different than those managed for wilderness. To find out the forest objectives, youth can ask the manager or observe uses, evidence of harvesting, diversity of species, the kinds of species, and randomness and spacing of the trees.

Because of varying types, uses, and management practices, not all forests will have all three clearly defined layers. For example, layers in a young
PLT connection: In Activity \#32, youth brainstorm ways they personally benefit from forests such as recreation, wildlife protection, and useful products and then simulate managing a forest for different objectives in $\boldsymbol{A}$ Forest of Many Uses. Activity \#33, Forest Consequences, gives youth a taste of the compromises that must be a part of land use decisions by having them discuss how a piece of forested land should be managed. In Activity \# 35, Loving It Too Much, youth explain how park ecosystems can suffer from overuse and activities outside the park, and then explore the pros and cons of possible solutions. In Activity \#50, 40oAcre Wood, teams of youth create a management plan for a piece of public forest and then evaluate all of the plans based on how they meet specific objectives. 
forest may not have developed yet, a forest may only have tall trees, or a forest may have layers that blend into each other.

Human activity in a forest can alter it through many ways including harvesting, silvicultural activities, construction (even just of trails), misuse, disturbance of wildlife, or prevention of fire.

Managers can have management plans that will lead to specific changes in the forest or that will cause the forest to change less rapidly. Not having a plan will pretty much guarantee some kind of change, but maybe one that is not desired.

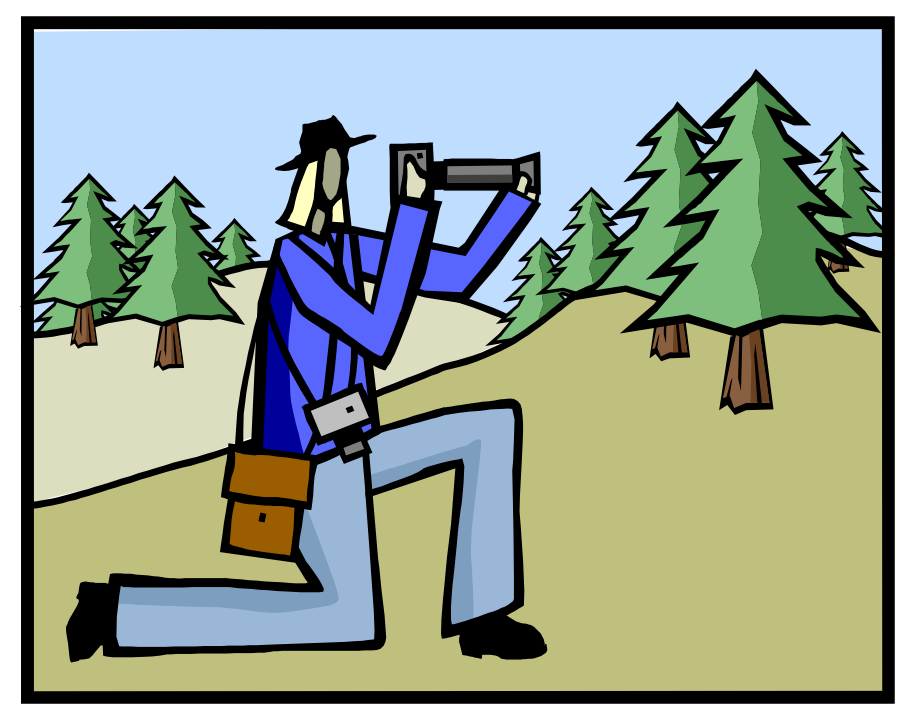




\section{Activity 1.3: \\ Not All the Same}

\section{Life Skill: Learning to learn \\ Project Skill: Creating an imaginary forest What to Do: Choose a Florida forest type and invent a forest that fits the characteristics of that type.}

The factors that combine to make each type of Florida ecosystem unique include temperature, rainfall, soil type, drainage, nutrient level, elevation, and proximity to other ecosystems and water sources. Go out into the forest ecosystems with your youth and either take field guides with you to identify plants and animals, or take notes, pictures, and drawings to compare with the pictures on the 4-H Forest Ecology web site (www.sfrc.ufl.edu/4h). Challenge the youth to identify the environmental needs of each plant and animal they find and confirm that those needs match the factors provided in that ecosystem. Most plants and animals take advantage of every environment they can survive in. Encourage your youth to show how the different components of their forest work together to make a functioning ecosystem rather than a place with lots of individuals living near each other.

\section{Discussion Question Clues:}

Because Florida has such a vast array of climates, soil types, moisture levels, and modest differences in elevation, our state supports many different types of forest ecosystems. Changes in water level (higher along the coast, or lower in a swamp) that are sustained over time may result in tree mortality and could eventually change the ecosystem.

Depictions of any forest ecosystem usually prominently feature the dominant tree species or conditions that make it unique--water in a swamp, sand pine in the scrub, or plantations in the flatwoods.
PLT connection:

Activity \#20, Environmental Exchange Box, enables youth to compare other environments with their own by trading a box of information about their forest with a group. Activity \#29, Rain Reasons, shows youth how climate impacts plant growth and the presence of wildlife and plant life in a certain region.

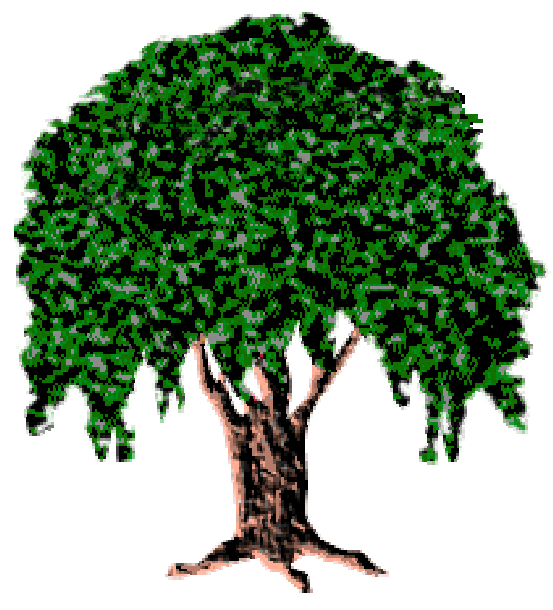




\section{Activity 1.4: \\ Forest in the City}

\section{Life Skill: Leading self and others Project Skill: Conducting an inventory What to Do: Explore an urban forest and collect data.}

This activity enables 4-H'ers to explore the urban forest. If your urban forest is large, make sure your 4-H'er selects a reasonable portion of the forest to inventory.

Trees in urban forests are more vulnerable than trees in other kinds of forests. There are probably trees in your urban forest that have some of these problems: 1) air and water pollution, 2) vandalism, 3 ) being surrounded by pavement and sidewalks so their water sources are limited, 4) bark or root damage from lawn mowers or cars, 5) elevated temperatures, or 6) soil compaction making it difficult for roots to grow, get oxygen, and absorb nutrients and water. If damage to trees is significant, it can stress the trees. When under stress, they might succumb to insects or diseases. Trees in urban areas often have a shorter life span than their rural counterparts. In the central, urban core, trees live only about an average of seven years.

When inventorying wildlife, scientists usually find squirrels, birds, and creatures which can tolerate people. Encourage your 4-H'ers to look for evidence of other animals that might not show themselves when people are around. Their signs include tracks, holes, scat (feces), partially eaten leaves or nuts, and nests.

\section{Discussion Question Clues:}

These three inventories reveal clues about the urban forest ecosystem: the ways that people use the forest, the types of animals that live in this ecosystem, and tree species found there. These three elements might indicate something about
PLT connection: Activity \#30, Three Cheers for Trees, helps youth imagine life without trees and the many benefits we receive from trees. In Activity \#55,

Planning the Ideal Community, youth examine the resources in their community that meet human needs and then design an ideal community that will meet everyone's needs. Activity \#47, Are Vacant Lots Vacant?, allows youth to examine the plant and animal life that flourishes in a vacant city lot.
$-42-$

Florida's Fabulous Forests 
current management practices, future uses, and problems for the area.

Inventories of an urban forest will provide information that urban foresters can use to improve a forest and emphasize its benefits. Trees act as air purifiers by absorbing carbon dioxide and filtering other pollutants. Urban forests provide homes for many other plants and for animals, create shade, and prevent erosion. For many residents, they are aesthetically pleasing and provide a place for relaxation and recreation (which can improve and maintain mental health). Forests also provide communities with a sense of pride. Everyone benefits from the ecosystem services that an urban forest offers.

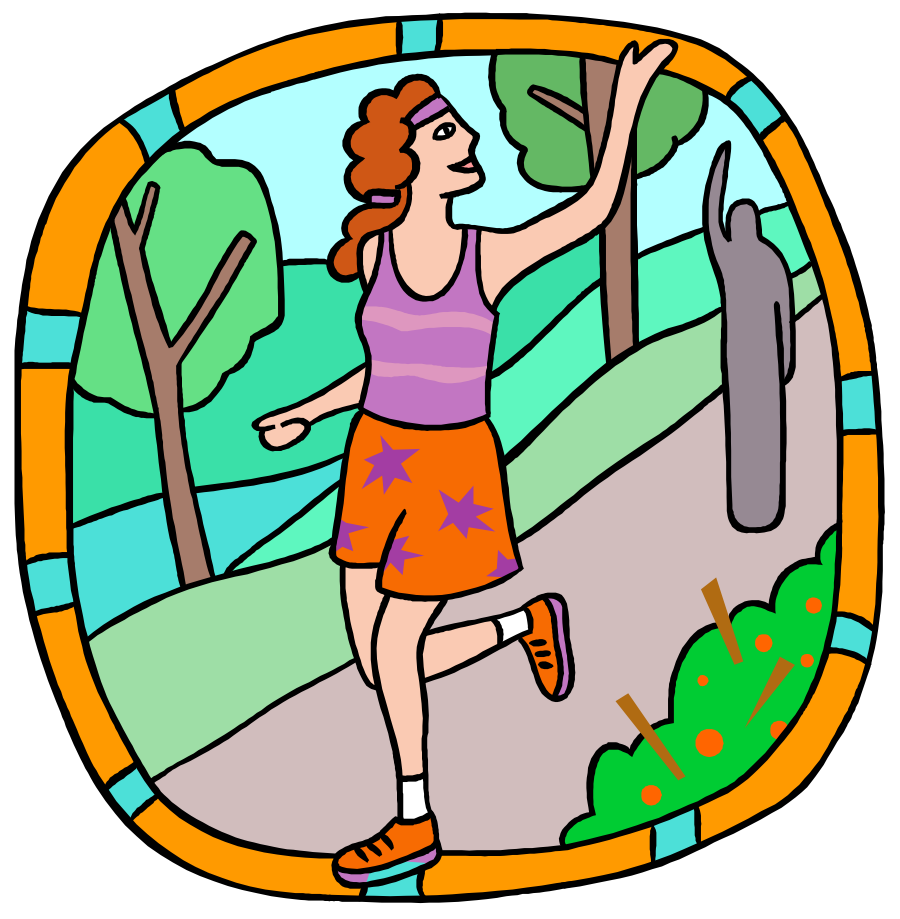




\section{Activity 1.5: A Working Forest}

\section{Life Skill: Relating to others \\ Project Skill: Understanding what a plantation is \\ What to Do: Visit and tour a plantation}

Plantations are the dominant forest type in some parts of Florida. These working forests produce an enormous variety of useful products and jobs. It is important for Floridians to understand how these plantations are managed.

By visiting a plantation and talking to a knowledgeable landowner, your 4-H'er will have additional, first-hand knowledge of this forest type. If you don't have a public forest nearby, contact the Florida Forestry Association (850-2225646 ) to see if a family tree farm or industryowned property is near you. Call ahead to arrange a visit, and ask to see several different forest stands with different ages of trees. A forest of $5^{-}$ year old trees will be quite different from a 40-year old stand.

\section{Discussion Question Clues:}

No matter what products plantations ultimately provide, they also act as air purifiers, homes to wildlife, wooded roadsides, and recreation sites. Plantations also provide jobs and economic revenue.

Management plans help keep the forest on track to meet the landowners' goals. Since forest managers cannot always predict what will happen, these plans must be flexible and change with the needs of the forest. Insect pests, weather damage, and drought can require a change in a management plan. All types of forest should have some sort of plan, even if that plan is to allow the forest to evolve and change naturally. Other natural resources like water, soil, and wildlife are managed too, though when these resources cross ownership boundaries, they are much harder to manage!

\section{PLT connection:} Activity \#69, Forest for the Trees, is a role-play where youth learn how managers make decisions for private forests based on economic factors.

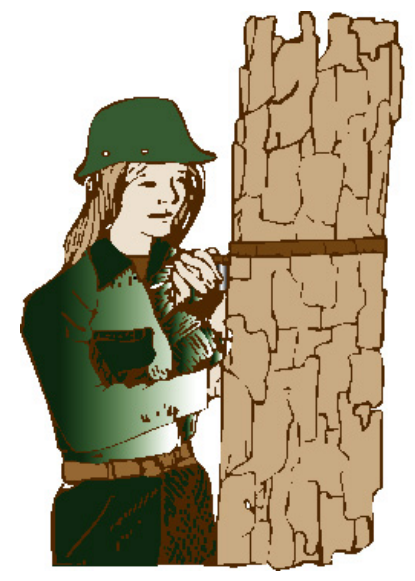




\section{Chapter 2: Elements of Forests}

\section{Activity 2.1: Who Calls this Home?}

\section{Life Skill: Applying science process skills Project Skill: Gathering and recording data What to Do: Examine a fallen, rotting log and record data about what is seen.}

Many of the organisms that help decompose leaves, branches, roots, and tree trunks can be found in a rotten log. As much as youngsters may wish to tear apart a decomposing log, encourage them to explore with care, as scorpions and other biting creatures might live there. Challenge them to investigate the log in such a way that they can put it back in pretty good shape. If a skunk should wander by looking for an evening meal, for example, it should be able to find a log, not a pile of wood chips. The group should do no more damage than a wild animal looking for lunch. They might consider rolling the log to see what is living underneath, but make sure they are careful! A snake might be hiding there.

\section{Discussion Question Clues:}

If this is an average, typical log, the organisms found here are probably present in the other rotting logs in the forest. Most of these creatures play one role in the forest ecosystem, helping to decompose vegetation. The log itself is a community of interactive organisms. All of the plants, animals, bacteria, mushrooms, and protists in the log interact in a variety of ways-they compete, they eat, and they support each other. This small community is a snapshot of what is happening in the whole forest. Since scientists can't look under every log, they use a few representative logs to give them a sense of what is happening in the broader area. Other scientists use this process of sampling and observing the environment to learn about the world.
PLT connection: Activity \#23, The Fallen Log, is a very similar activity to this one. Activity \#24, Nature's Recyclers, investigates sowbugs, what they eat, and how they scavenge. Activity \# 26, Dynamic Duos, demonstrates symbiotic relationships in nature through a game of matching critters to an appropriate classified advertisement.

Materials Needed: Magnifying glasses

Forest Resource Box:

In the box, you will find a variety of items that can be used with this activity: magnifying glasses, bug boxes, and petri dishes. 
Animals are sensitive to changes in their environment. For a tiny decomposer, the difference between the sunny and shady side of the log could change the temperature, moisture availability, and populations of bacteria and mushrooms. Depending upon the log, this could mean two different communities occupy the log.

The insects and other organisms illustrated in the project book are likely to be found in the log, but other animals are possible, too. Encourage the youth to use a field guide or two to identify the creatures they find. If they didn't take a book to the log, they will have to make careful descriptions of colors, size, and identifying marks. Ask them to hypothesize where else they might find these organisms: under a rock? under the leaf litter?

Soil organisms are often forgotten in the excitement of protecting biodiversity in a forest. People tend to think of birds and bears before they think of springtails and centipedes. But tiny creatures play a valuable role in maintaining ecosystem services like decomposition and forming the base of a forest food web.

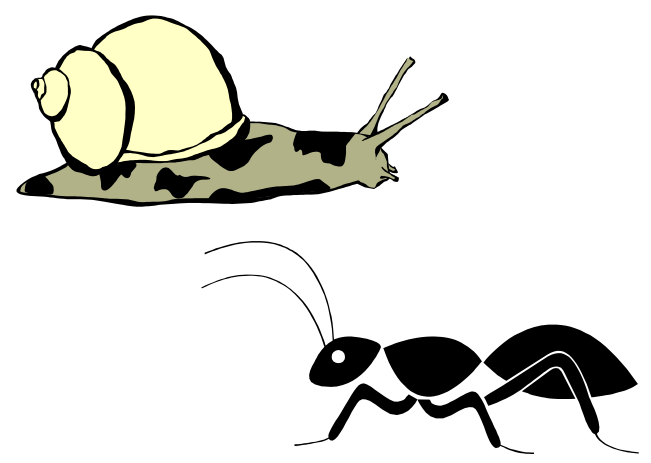




\section{Activity 2.2: \\ A Wild Life!}

\section{Life Skill: Planning and organizing Project Skill: Creating an animal-friendly habitat \\ What to Do: Research a local animal and enhance its habitat.}

Many animals can be attracted to school sites, backyards, and forest parks by improving the habitat. By providing for animals' food, nesting sites, water, and shelter, new animals may move to the area. Encourage your 4-H'er to investigate the animal's needs over time, through different seasons, and as the creature grows. Butterflies need different plants if they are caterpillars or adults. The Florida Fish and Wildlife Conservation Commission has a publication, "Planting a Refuge for Wildlife: How to create a backyard habitat for Florida's birds and beasts," that can provide more information. Contact the FWCC at (850) 488-4676 to obtain a copy of the booklet. The Department of Wildlife Ecology and Conservation at the University of Florida also has a variety of helpful fact sheets and a website http://www.wec.ufl.edu/extension. Your 4-H'er may wish to compete in the Wildlife Habitat Evaluation Program, too.

\section{Discussion Question Clues:}

Before attracting vulnerable wildlife to a new area, youth should evaluate the risks that already exist. For example, if there are outdoor cats in the area, it might be a bad idea to try to attract small mammals or birds. Auto traffic and landscaping plants might not mix well with an increase in the deer population, either. For animals with a large home range, one backyard may not be enough. A neighborhood or community effort may be required to protect and enhance enough habitats to really make a difference.
PLT connection: In Activity \#22, Trees as Habitats, youth will investigate the plants and animals that live in, on, or around trees. In Activity \#45, Web of Life, youth will make a mural about the interdependence of organisms living in a forest.

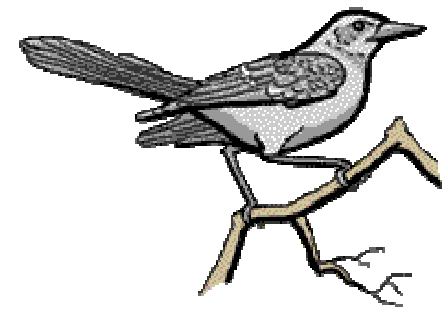




\section{Activity 2.3: \\ In Danger}

\section{Life Skill: Communicating with others Project Skill: Researching and presenting a topic \\ What to Do: Select an endangered species and create an information campaign.}

There are many different ways we can provide help to endangered animals. Some may need protection for habitat, others may need existing habitat managed in a certain way. Some may do better if people change key behaviors, like letting pet cats roam free in scrub jay territory, or speeding in a motorboat through manatee feeding grounds. Communication campaigns are tools that can be used to alert people to the things they can do to help endangered species. This activity requires a 4H'er to investigate one endangered or threatened forest species in Florida and design an information campaign for it. One key about a campaign is to carefully select the audience. Assist the 4-H'er by reminding him or her to establish an objective for the campaign and to keep that objective in mind throughout the planning stage. Help your 4H'er think of ways that the loss of their species would impact their audience.

At the bottom of page 30 of Florida's Fabulous Forests, in the box in the right corner, the first question should read: What is your objective?

Here is an example of an information campaign:

Species: Flatwoods Salamander Who is the audience: Forest Landowners in north Florida

What should people know: That salamanders live in the soil within 1.5 miles of a shallow pond in the flatwood forests.
PLT connection: Activity \#57 helps youth learn about

Democracy in Action by researching groups, agencies, or organizations that have a role in environmental policies. In Activity \#60, youth design a community action project and use various forms of media to Publicize it! 
What is your objective: To increase awareness about flatwood salamanders and encourage forest management techniques that do not disturb the soil near ponds.

Getting the message across: Flyer at the grocery store in town; a brochure mailed to forest landowners; and a display at the public library.

\section{Discussion Question Clues:}

All species are in constant interaction with other species; none lives in a vacuum. Sometimes it is difficult to know how important any one species really is to the ecological stability of a forest. Some degree of change is normal for a forest, but at some point, the loss of species may be too great and the system will not operate as it once did. As development increases across the globe, communities will make decisions to protect or to lose biodiversity. What is enough? What is acceptable loss? Future citizens will make these decisions often. Biologists have determined that some animals and plants are "keystone species"-their role in the system is so important that other plants and animals depend upon them. Elephants, kelp, and gopher tortoise are some examples of keystone species. Efforts to maintain their populations often bring benefits to the entire ecosystem.

People also have intrinsic reasons to care about a species--they find it beautiful, intriguing, or deserving of respect. Others are motivated to protect endangered species because of their religious beliefs, because of the economic potential for new drugs or foods, or because they feel responsible to assist the species that are in trouble because of human activities. 


\section{Activity 2.4: Get Your Hands Dirty}

\section{Adopt a Tree Life Skill: Applying science process skills \\ Project Skill: Observational and experimental skills \\ What to Do: Dig a hole to examine the soil and test for soil drainage}

Soil forms the foundation of every forest. This activity explores what is under the soil's surface by digging a hole. Help your 4-H'er find an appropriate place to dig a hole big enough to see several layers of soil. Because of how developers build homes, your backyard probably is not the best place to see natural soil horizons. The hole should be filled in when the activity is completed. Your county agriculture agent or Natural Resource Conservation Service staff person can help provide you with information about the soils in your area and what crops are grown where. This activity directs youth to explore the soil layers and conduct an experiment. Your job is to maintain an air of scientific investigation: ask what question they are trying to resolve, prompt them to provide a hypothesis and prediction about the results, and remind them to repeat the experiment to confirm their hunch.

\section{Discussion Question Clues:}

The nutrients in and the water-holding capacity of soil determine which plants grow there and how well they do. Of course, the plants help determine what animals and other organisms live in an ecosystem. Fertilizers can change the nutrient level of soil. Fire may add a thin level of ash or charcoal to a soil horizon. Storms that uproot trees can change a soil horizon at that point; bulldozers and home construction can change the soil horizon in an entire neighborhood. It might be interesting for your 4-H'er to examine a hole in the ground to see how much of the soil horizon was disrupted.

\section{PLT connection:} Activity \#70, Soil

Stories, explains why soils have so much impact on what types plants live in certain areas.

\section{Materials Needed:}

Shovel, large tin can, can-opener, ruler, water, and watch

Forest Resource Box: You will find a large tin can that has already had its top and bottom removed. There is also a ruler in the box. 


\section{Activity 2.5: Forests in the Rain}

\section{Life Skill: Applying science process skills Project Skill: Conducting experiments What to Do: Explore how forests and soil interact with water.}

This experiment explores the value of leaf litter on forest soils when it rains. Additional experiments can be designed and conducted to explore the value of the leaf canopy (encourage experimentation with a sprinkler on a bush) or other aspects of the water cycle in forests.

\section{Discussion Question Clues:}

Roots help hold soil in place. Both the "top" and the "bottom" of the tree help allow water to seep into the ground and then the water table. If the ground is saturated, a good network of roots in the soil will help keep the soil in place and make the water that runs off the surface free of soil. This helps keep the streams and lakes cleaner. Forest plants also give off water during the daytime while photosynthesis occurs. The entire water cycle, from rain to earth to atmosphere, happens in the forest!

All of Florida falls into one of the following Water Management Districts. Their boundaries are determined by watersheds. These agencies help manage and protect water quality. They each have a website and lots of educational materials.
PLT connection: In Activity \# 38, Every

Drop Counts, youth

learn ways to conserve water and about the benefits it can provide. In Activity \#44, youth learn about Water Wonders through simulating the water cycle. Activity \#71, Watch on

Wetlands, explores a wetland ecosystem and the issues surrounding its protection and management.

\section{Materials Needed:} Watering can, two pie plates, soil, leaf litter, and two bowls

Forest Resource Box: You will find two pie plates in the box.

Northwest Florida Water Management District http://www.state.fl.us/nwfwmd Suwannee River Water Management District http://www.srwmd.state.fl.us St. Johns River Water Management District http://sjr.state.fl.us South Florida Water Management District $\quad$ http://www.sfwmd.gov Southwest Florida Water Management District http://www.swfwmd.state.fl.us 


\section{Activity 2.6: \\ It's Natural to Succeed}

\section{Adopt a Tree Life Skill: Communicating with Others \\ Project Skill: Interviewing people What to Do: Research and share the history of nearby forests.}

In addition to death and taxes, the only thing that one can be sure of in this world is that things will change: communities grow, buildings fall down, mountains erode, stream channels move. Forests, too, change. Shade-tolerant trees grow up under sun-loving trees, changing the composition of the forest. Since most trees live longer than people, this type of change is hard to detect. One of the easiest ways to capture change is to research land use patterns, interview people, and search for documents and photographs that may describe an area over time. Youth will practice their research and interviewing skills in this activity to explore forest change. By choosing two different forests, it will be possible to at least compare their histories. Your 4-H'er may need help finding people to interview who have been in the area for at least 1025 years.

\section{Discussion Question Clues:}

Studying history can put a new perspective on the present and the future. A lot can be learned from discovering all the different land uses over time in one area. A plantation on land that was once a pasture will look different than a plantation on land that was previously in trees. If a plantation has been harvested twice in 50 years, perhaps the current trees are not destined to become tall and huge. The history of forests is also a history of human ingenuity and changing social views. Fires, hurricanes, and floods are three very common events in Florida forests that can "set back" succession. The appearance of invasive exotics can change the composition of a forest, but not in keeping with the predictable process of succession.
PLT connection: Activity \#40, Then and Now, helps youth rate environmental changes that have occurred in their community and come up with solutions for the negative changes. Activity \#80, Nothing Succeeds Like Succession, explores connections among biodiversity, ecosystem resilience, and succession. Activity \# 95, Did You

Notice? examines ecosystem change.

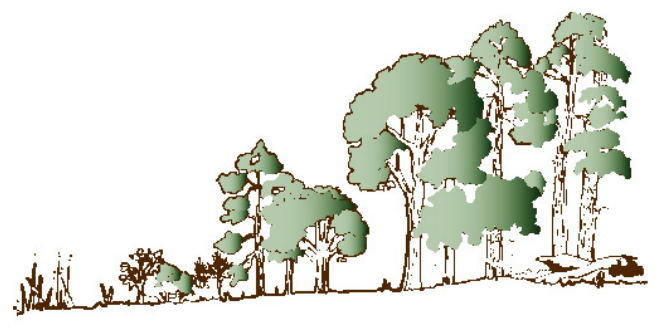

$-52-$

Florida's Fabulous Forests 
By using people as a source of historic information, 4-H'ers may glean an emotional connection to a forest that would be missing from maps and news reports. Interviewees may also have a less-than-accurate memory.

If a community decides to protect a stand of pine trees by leaving it alone, it will definitely not remain the same. To maintain the pines, they may need to remove invasive species, use prescribed fire, open patches of sunlight for young trees to grow, and perhaps plant seedlings. What any forest will look like in 5,10 , or 50 years will depend partly on what is currently growing, how the land around the forest is zoned, and how the land is managed.

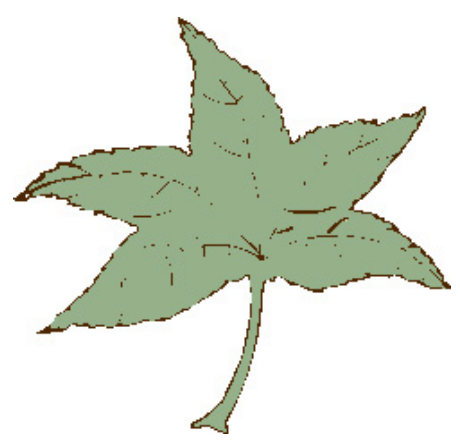




\section{Chapter 3: Managing Forests}

\section{Activity 3.1: It's Not So Clear Cut}

\section{Life Skill: Relating to others Project Skill: Conduct an opinion poll What to Do: Learn about timber harvest and what others know}

Of all the forestry practices, clearcutting is perhaps the most controversial. People in West Virginia went to court to stop it many years ago; people in the Pacific Northwest recently launched a citizen referendum to prevent it. In Florida clearcuts draw less attention, perhaps because this technique is usually practiced on privately owned plantations or because our flat landscape does not reveal large expanses of forests. As with most controversies, there is plenty of misunderstanding and a healthy dose of varied opinions. Some people may not realize that there is a difference between clearcutting for timber and land clearing for development. This activity provides good practice in exploring fact and opinion through an opinion poll and subsequent conversations. Most people have strongly held notions for good reasons. Perhaps your 4-H'er will help some people understand a little more about how others see the issue. Make sure they review the Clearcut Facts on page 43 of Florida's Fabulous Forests and thoroughly understand the different harvesting techniques on pages 41-42.

\section{Discussion Question Clues:}

When talking to people about a controversial issue like clearcutting, people may react in a variety of ways. They may jump at the chance to express their view, they may be afraid to talk, or they may recognize their confusion. Those who believe strongly in their opinions may be challenging to talk to, but it does not make their ideas more or less important. Their opinions may be so firmly set that
PLT connection: In Activity \#19, Values of the Line, youth talk about their feelings concerning environmental issues and learn how to listen to opposing views. Activity \#33, Forest Consequences, examines the results of human activities. Activity \#69, Forest

for the Trees, is a role-play where managers make decisions for private forests based on economic factors. 
they are unwilling to listen to alternative information. How a question is asked can have a big impact on how people respond. Interviewers try to be as neutral as possible when talking to people so they don't sway or prejudice the answers. The following two questions may elicit different reactions, even though they ask about the same thing:

Do you think it is important to provide people with toilet paper, lumber, newspaper and other wood products by harvesting trees?

Do you think killing mature, old-growth trees just for profit is wrong?

This same poll could have had open-ended questions where respondents give an answer in their own words, multiple choice, true/false, or attitudinal questions. All of them could be helpful in determining what people know about clearcutting. Open-ended questions are often the most valuable, but the hardest to analyze.

However, this is one of the only ways to know if the respondents give the right answer for the wrong reasons!

Most forests are clearcut to increase harvest and reforestation efficiency by opening the plot for planting new, superior pine seedlings. These seedlings require full sun for fast growth, which means few if any trees should be left to shade them. Clearcuts also allow the forest landowner to remove shrubs and other plants that compete with seedlings for nutrients.

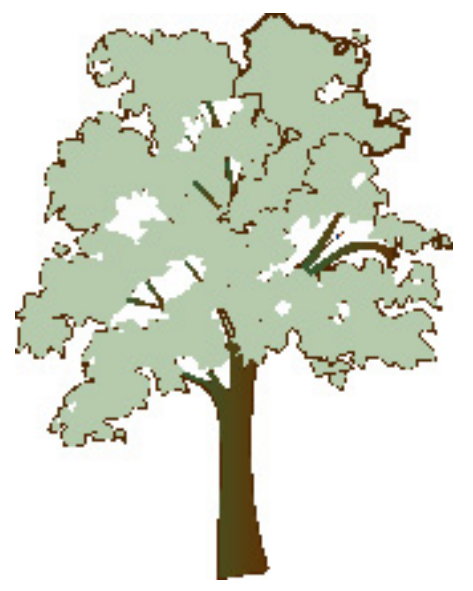




\section{Activity 3.2: \\ Tree Doctor}

\section{Life Skill: Learning to learn \\ Project Skill: Recognizing forest insect and disease damage \\ What to Do: Look for signs of damage on trees and build models of insects.}

Insects are part of a natural forest ecosystem. That means there are always some insects or other animals eating, laying eggs, moving around, or building a shelter in trees. Most forests tolerate small numbers of insects and pathogens quite well. If the insect population or disease becomes an epidemic, however, strong control measures may be in order. 4-H'ers can be of service by learning the telltale signs of local insect and disease problems and alerting a local arborist or county forester about a potential concern.

\section{Discussion Question Clues:}

Trees can be weakened by fire, lightning, strong winds, and drought. If these things do not kill a tree, they might leave the tree vulnerable to insects and pathogens. Foresters can help keep a forest healthy by removing weak trees, using fire or herbicides to reduce competition, applying pesticide to remove some insects and diseases, and planting the right tree in the right place. Genetically improved stock may also help resist certain diseases. After exploring this issue, the group may wish to debate when genetic modifications are appropriate and when they are considered "tampering with nature."
PLT connection: Activity \# 26, Dynamic Duos, demonstrates symbiotic relationships in nature through a game with classified ads. In Activity \#77, Trees in Trouble, youth examine conditions that affect human and plant health and learn about agencies that specialize in plant health.

Materials Needed: Clay, paint

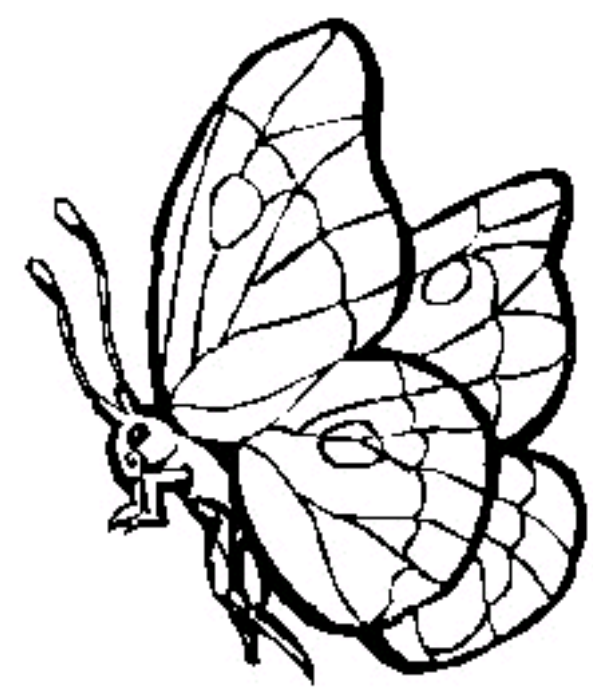




\section{Activity 3.3: \\ Friendly Flames}

\section{Life Skill: Communicating with others Project Skill: Writing a newspaper article What to Do: Research prescribed fire and write a newspaper article.}

There are two different kinds of fire in Florida's forests: wildland fire which may start by lightning, carelessness, or arson; and prescribed fire which is lit only when weather and forest conditions are right for controlling the blaze. Both kinds of fire can have benefits to the forest, but because so many people live in and near the forest, it is not likely that wildland fires will be allowed to burn. They will be put out by firefighting efforts.

If people do not realize there are two types of fires and that there are benefits to fire in Florida's forests, they may not support the use of prescribed fire in nearby natural areas. After doing some research on this issue (start with the County Extension Office and the EDIS system), your 4H'er may be able to help the public learn important facts about fire.

\section{Discussion Question Clues:}

Florida residents should learn there are two different kinds of fire, wildfire and prescribed fire (used to meet specific land management goals). Prescribed fires require a permit and are only conducted with appropriate weather conditions and appropriate firefighting equipment on hand. The benefits of managing the land with fire include: reducing hazardous fuel loads that may contribute to a wildland fire; increasing the nutritional value of sprouting vegetation for grazing animals; prompting flower and fruit production in wildflowers and shrubs; improving wildlife habitat; decreasing pest insect, pathogen, and plant populations; and improving soil fertility. Prescribed fire still produces smoke that can affect
PLT connection: In Activity \#59, The Power of Print, youth learn how objective and subjective points of view can be used to convey an environmental message. In Activity \#60, youth come up with a community action project and use the various forms of the media to Publicize it! 
human health and cause road hazards so the public needs to know about an upcoming prescribed fire in their area. There are many ways to inform people about prescribed fire including educational meetings near places that will be burned, public service announcements on TV and the radio, brochures, fliers, and public educational programs.

Fire prevention is not the only situation in which ecosystems suffer because people are focused on human benefits. Other examples include filling in wetlands, coastal development, forest fragmentation, and air and water quality degradation. Humans can make some sacrifices to improve these situations by planning ahead, reducing their consumption of resources, investing in pollution control measures, and exploring reasonable alternatives.

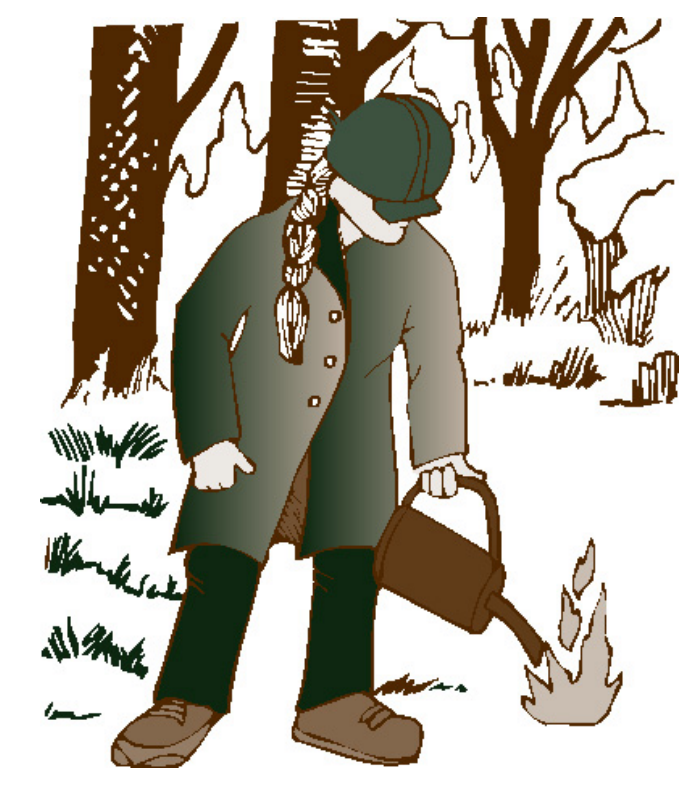

$-58-$

Florida's Fabulous Forests 


\section{Activity 3.4: \\ Be Prepared!}

\section{Life Skill: Making decisions \\ Project Skill: Conveying important information \\ What to Do: Create a model or drawing that shows how to landscape for fire.}

Most coastal residents prepare for hurricanes during hurricane season. It is not unreasonable to expect that forest residents should prepare for wildfire during fire season. There are a variety of ways to modify a house or landscape to reduce the risk of wildland fire. Information is available through the County Extension Office, Division of Forestry offices, and FIREWISE website (see pages 61-62).

The guidelines provided in this activity will help youth determine if their home or neighborhood is at risk of wildland fire. If a homeowner is at risk, he or she can reduce that risk with the landscaping guidelines on page 51 of Florida's Fabulous Forests.

\section{Discussion Question Clues:}

If people knew their risk for wildfire, they might work to improve their chances of surviving the next wildfire unscathed. Those who live in urban areas with fire hydrants and lots of cement may not need to worry about landscaping their yards for fire. For them, the environmental benefits of trees for shade, native shrubs for wildlife and mulch far outweigh the risk of fire. The chances of a wildfire reaching them are low. People who live near undeveloped land, however, should evaluate their risk and consider reducing vegetation.

Hurricanes, tornadoes, floods, and fires could threaten many Florida homes. People may think that because these are natural events, they pose no risk. Convincing residents who border undeveloped, unmanaged land that they really are at risk may be a challenge.
PLT connection: In Activity \#81, Living

With Fire, youth explore the positive as well as negative roles of fire and the options for forest fire management.

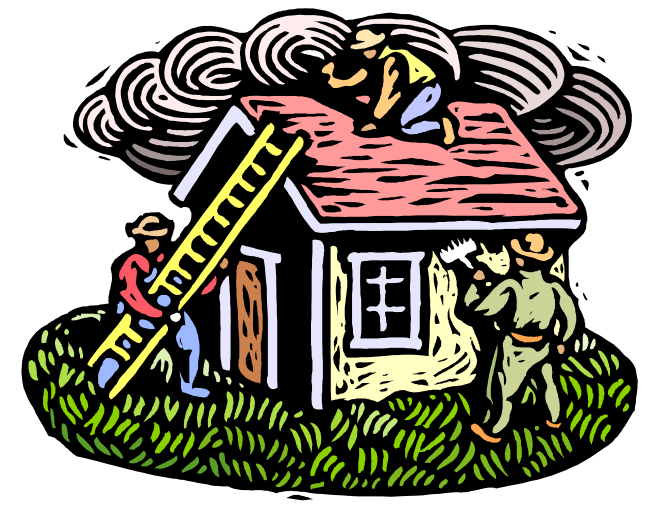




\section{Activity 3.5: \\ Visitors From Far and Away}

\section{Life Skill: Problem solving Project Skill: Identifying and removing invasive non-native plants What to Do: Visit a local natural area and identify invasive non-native plants.}

Land managers across Florida work hard to protect their natural areas from invasive exotic plants. Many of them would probably enjoy some 4-H energy to pick up air potatoes, package up climbing fern fronds, pluck water hyacinth from the water, and pull up mimosa and melaleuca seedlings. Make sure that everyone has appropriate training and protective gear, particularly if pesticides are being used.

In the end, stopping these plants before they get a foothold in a natural area is the best preventative measure. Encourage your youth to investigate the plants that are doing the most harm in your local area. Does everyone know of their invasive qualities? Are they coming from suburban lawns? What could 4-H'ers do about this problem?

Many invasive exotic organisms are changing Florida's landscape, not just plants. Fire ants and other insects, microbes, and pathogens have the potential to significantly change our ecosystems.

\section{Discussion Question Clues:}

When invasive exotic plants get started in a natural area, they can out-compete native species and limit the ability of wildlife to find food plants. They can also alter the function of an ecosystem by changing the water level and fire regime. They can be introduced on purpose: people might bring them in because they are beautiful or help hold erosive soil. Invasive plants might also hitchhike to Florida without being seen, by "catching a ride" on a sock, in a ship, with a bird, or in the soil of potted plants.

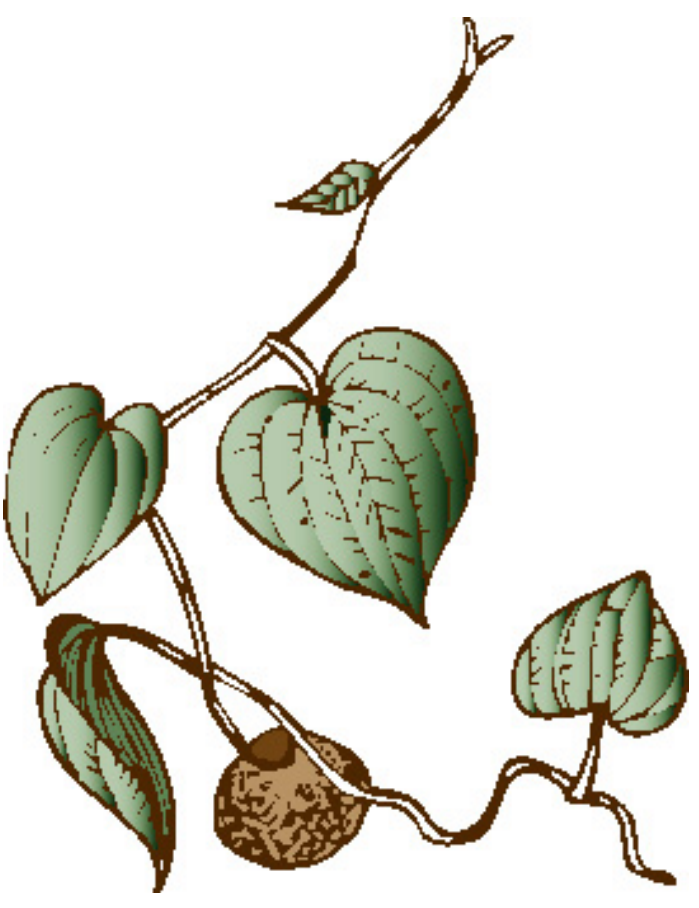

$-60-$

Florida's Fabulous Forests 
Many exotic plants are not invasive in natural ecosystems. Plants like oranges, basil, tomatoes, roses, and daisies stay in our groves and gardens and are quite useful. Invasive exotics, however, spread their seeds beyond the garden. If they thrive in Florida's climate, their populations keep expanding because they don't have natural predators or diseases or because they are simply better suited to this climate than the plants that are currently here.

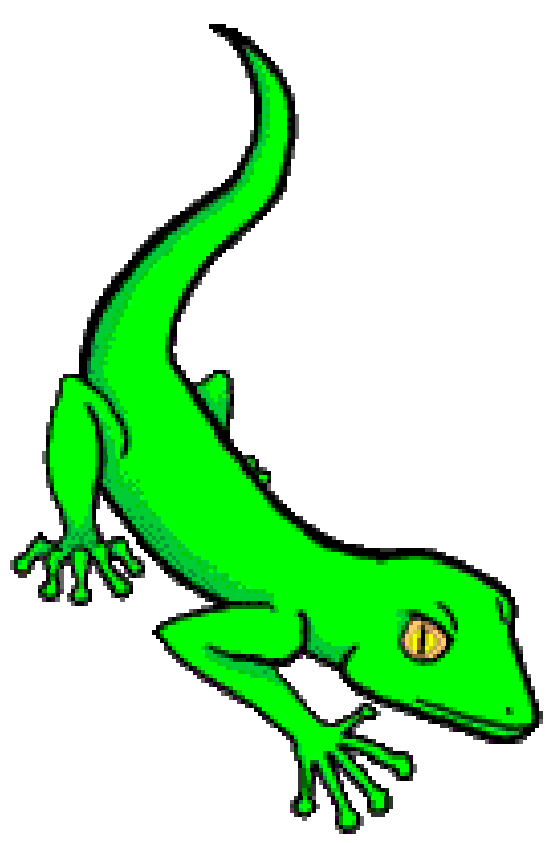




\section{Activity 3.6: \\ Enter Humans}

\section{Life Skill: Planning and organizing Project Skill: Creating and carrying out a plan \\ What to Do: Create and implement a plan to improve a park or forest.}

Many public parks and forests have management plans that help guide workers as they mow certain areas, cut new trails, plant young trees, harvest timber, remove invasive plants, apply prescribed fire, or control water run-off. There may be a natural area near you (a schoolyard, a park, or a forest) that needs to have a management plan, or needs an old plan updated. 4-H'ers could be involved in researching, discussing, designing, and implementing a management plan on some properties. Help work with the landowner (perhaps a 4-H parent or a public agency) to guide the youth and channel their energy. Youth can be involved in helping at a work-day, publicizing an area, or giving others the tools to be good stewards. Since trees can live a long time, it is important to write down management goals for future land managers and 4-H'ers.

\section{Discussion Question Clues:}

Some improvements can be long-lasting by being imbedded in an approved management plan. Others can be long-lasting because they were constructed out of high-quality materials. Still others may be long-lasting if younger 4-H'ers are trained to follow in the footsteps of the older 4H'ers, carrying out the same management goals.

Visitors to a forest can pay attention to the erosion caused by walking, to the ways water travels across the surface of the ground, and to the places where parking, camping, and climbing may compact the soil or kill plants.
PLT connection: In Activity \#17, People of the Forest, youth learn how people of the past and present have depended on forest for survival. Activity \#54, I'd Like to Visit a Place Where, helps youth recognize the importance of recreation areas to communities. Activity \# 96, Improve Your

Place, encourages youth to make some positive environmental changes in their community.

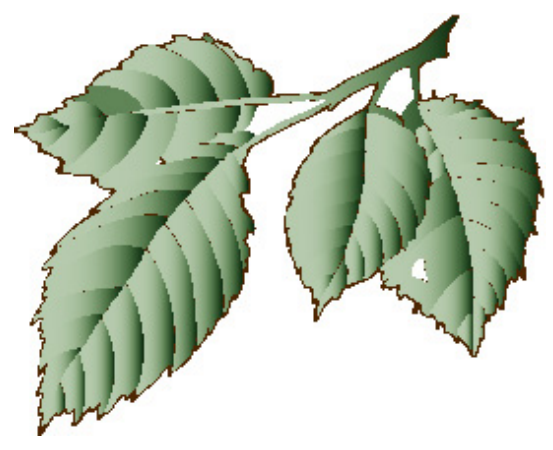


Becoming a forest steward can take many different roles in the various forest ecosystems. Knowing what is growing in the forest, what should be growing, and how forests can be kept healthy is part of the challenge. Understanding the threats to healthy forests and what we can do to reduce those threats is part of good stewardship. Using only the resources we need and being wise about how we use energy and non-renewable resources are also part of being a steward of the planet.

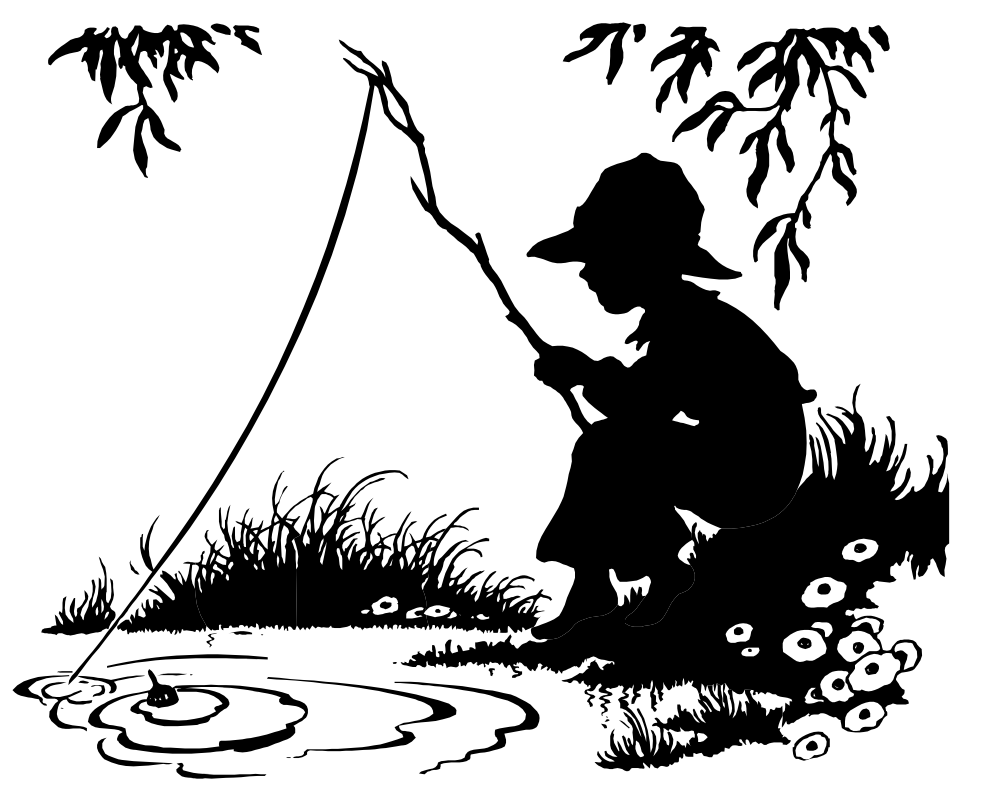




\section{Trees are the Earth's endless effort to speak to the listening heaven.}

--Rabindranath Jagore

Each generation takes the earth as trustees. We ought to bequeath to posterity as many forests and orchards as we have exhausted and consumed.

--J. Sterling Morton

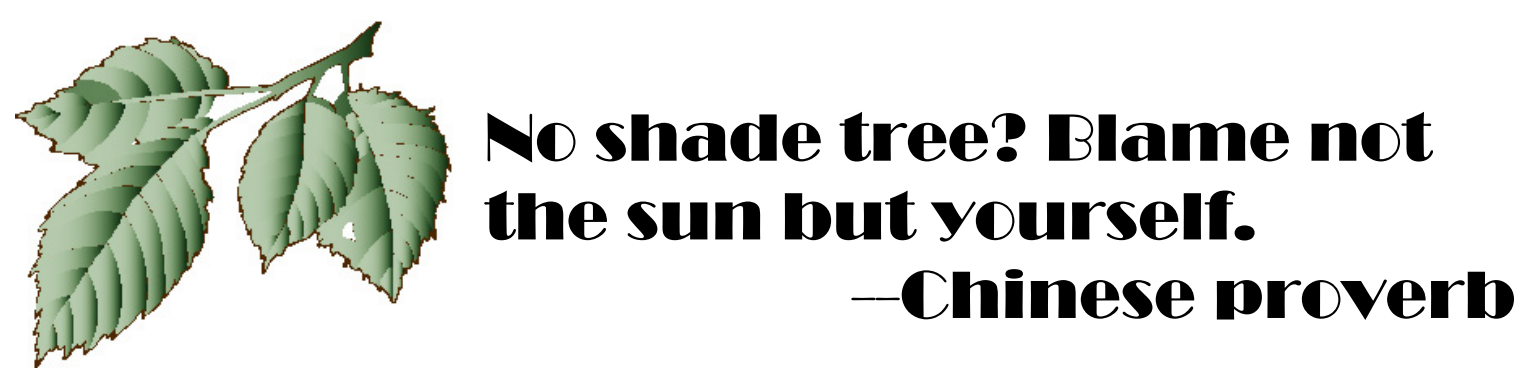

To exist as a ration, to prosper as a state, and to live as a people, we must have trees.

--Theadare Roosevelt

He who plants a tree plants a hope.

- Lucy Larcom

COOPERATIVE EXTENSION SERVICE, UNIVERSITY OF FLORIDA, INSTITUTE OF FOOD AND AGRICULTURAL SCIENCES, Christine Taylor Waddill, Director, in cooperation with the United States Department of Agriculture, publishes this information to further the purpose of the May 8 and June 30,1914 Acts of Congress; and is authorized to provide research, educational information and other services only to individuals and institutions that function without regard to race, color, age, sex, disability or national origin. The information in this publication is available in alternate formats. Single copies of extension publications (excluding $4-\mathrm{H}$ and youth publications) are available free to Florida residents from county extension offices. Information on copies for out-of-state purchase is available from IFAS-Extension Bookstore, University of Florida, PO Box 110011, Gainesville, FL 32611-0011. Information about alternate formats is available from IFAS Communication Services, University of Florida, PO Box 110810, Gainesville, FL 32611-0810. First printed: October 2001. 